\title{
A Scoping Review of Ontologies Relevant to Design Strategies in Response to the UN Sustainable Development Goals (SDGs)
}

\author{
Jyh-Rong Chou (1)
}

check for updates

Citation: Chou, J.-R. A Scoping Review of Ontologies Relevant to Design Strategies in Response to the UN Sustainable Development Goals (SDGs). Sustainability 2021, 13, 10012. https://doi.org/10.3390/su131810012

Academic Editor: Yoshiki Shimomura

Received: 9 August 2021

Accepted: 4 September 2021

Published: 7 September 2021

Publisher's Note: MDPI stays neutral with regard to jurisdictional claims in published maps and institutional affiliations.

Copyright: (C) 2021 by the author. Licensee MDPI, Basel, Switzerland. This article is an open access article distributed under the terms and conditions of the Creative Commons Attribution (CC BY) license (https:// creativecommons.org/licenses/by/ $4.0 /)$.
Department of Creative Product Design, I-Shou University, Kaohsiung City 84001, Taiwan; jrchou@isu.edu.tw; Tel.: +886-7-6577711 (ext. 5031)

\begin{abstract}
Since the initiation of the 2030 Agenda for Sustainable Development in 2015, academia and industry have been taking action to seek how to address the Sustainable Development Goals (SDGs) via research, practice, and community engagement. Due to the UN SDGs comprising comprehensive domain-centric ontologies for reaching a consensus on their achievement, so far there has been a literature gap on how and what product design strategies can help achieve which of the SDGs. Inspired by the implication of creating a better world with design, this study conducted a scoping review to synthesize existing design strategies toward the implementation of the SDGs. More than 110 design strategies/methods were collected and synthesized as evidence to map onto the ontological domains of the SDGs. The results indicate that Goals 8, 9, 11, and 12Sustainable Development Goals can be correspondingly addressed by the current body of design strategies, whereas a gap exists in the design strategies to address Goals 15, 16, and 17. Most of the corresponding strategies can be workable to Goals 3, 4, 6, and 7 to a certain extent and, in a broad sense, are in line with the contextual implications of Goals 1,2, 5, 10,13, and 14. This study provides a useful starting point for researchers to explore how design has been contributing to the sustainability goals. It also contributes to existing knowledge of the design discipline by providing methodological guidance for researchers and practitioners to conduct further research and practice on the UN SDGs.
\end{abstract}

Keywords: literature review; design strategy; design method; ontological domain; scoping review; Sustainable Development Goals (SDGs)

\section{Introduction}

Industrialization plays a crucial role in promoting an ever-advancing human civilization. However, it contributes to negative externalities that could be harmful to either the general public directly or via the environment such as pollution, greenhouse gas emission, and global warming. There has been a significant income inequality between laborers and those who dominate capital resources due to the decoupling of capital and labor. The consequences of over-industrialization have resulted in a great impact on our society, economics, and environment. These effects are profound, ranging from human development, lifespan, and health span to social improvements and the impact on natural resources, public health and sanitation, energy usage, and biodiversity loss. Currently, the international community is at a historic crossroads, since the world is facing extreme challenges, not only climate change and environmental degradation but also many social and economic disturbances. Over the past few decades, there have been numerous advances in discussing sustainable development issues. Much more progress has been observed in developed countries, and many developing countries are also aware of the need of seeking sustainability. The concept of sustainable development was coined in a report by the United Nations Commission on Environment and Development (the commission later adopted the name World Commission on Environment and Development, WCED) entitled "Our Common Future" (also known as the Brundtland Report). It advocates that development should be planned in order to meet the needs of the present without compromising the ability of 
future generations to meet their own needs [1]. This concept implies conditional rather than absolute limits, where limitations were imposed by the current impact of technology and social development on environmental resources and by the capacity of the biosphere to absorb the impact from various human activities. However, Conard [2] indicated that most political leaders did not intend to act on the global sustainability agenda readily or significantly, still less on a more comprehensive list of challenges. The world needs distinct leadership and passionate efforts on sustainable development issues. In this context, the United Nations (UN) plays an important role in assisting countries to overcome present and future sustainability challenges, by which the Millennium Development Goals (MDGs) were established in the Millennium Declaration in 2000. These goals set eight initiatives to make the world a better place to live by 2015 [3,4]. The 2012 UN Conference on Sustainable Development (UNCSD), also known as "Rio+20" or "Rio Earth Summit 2012", is recognized as a historical event, as it marked the 20th anniversary of the UN Conference on Environment and Development (UNCED) held in 1992. It sought to ensure confirmations for the political commitments and established the global environmental agenda for the next two decades through discussing new and emerging issues.

"Rio+20" evinced the progress of international cooperation on sustainable development. However, there remained former problems worldwide to be solved, additionally the emergence of new and more complicated challenges with respect to an extensive range of global compact issues [5]. Serving as a continuation of the MDGs, the Sustainable Development Goals (SDGs) were created in 2015, whereby the SDGs are an integral part of the 2030 Agenda that is a formal declaration adopted by UN Members and attempts to address the global challenges we face. These goals are considered the most significant points for understanding and achieving human and environmental development ambitions up to $2030[6,7]$. In this context, incentives for research on sustainability have become even more crucial. The initiative of the UN SDGs is more profound and comprehensive than previous action plans created for sustainable development, involving high-level, cross-border cooperation with multidimensional political negotiations. According to Leal Filho et al. [8], the SDGs provide opportunities to reinvigorate the sustainable development research agenda, since the current progress is insufficient to keep humans from exceeding their limits on the use of natural resources. Salvia et al. [9] found that experts worldwide attempt to respond to many SDGs, according to their specialties and research areas, through examining emerging issues between these SDGs and the main local issues/challenges in each area. Ospina-Forero et al. [10] introduced the most suitable estimation methods for SDG networks and classified SDG studies into subjective and statistical ones, where the former relies on qualitative information (e.g., the conceptual description of the variables), while the latter makes use of panel data (e.g., data observations on different countries over time). Current research on the SDGs requires multidisciplinary, interdisciplinary, and transdisciplinary approaches to generating knowledge [11] in which hot topics include public health [12], management education [13], building assessment and management [14], environmental assessment and management [15], sustainable manufacturing [16], and food security and nutrition [17]. A considerable amount of research has been conducted with respect to the implementation and achievability of the sustainable development targets across distinct pathways and domains [18-21].

In addition to topic-specific research, literature reviews on SDGs have been conducted extensively in recent years to provide an overview of current knowledge and evidence and to allow researchers to identify relevant theories, methods, and gaps in the existing research. For example, Allen et al. [22] conducted a review of the evidence for 26 countries to analyze their initial progress in implementing the SDGs. They found that there has been some progress in initial planning stages, but there are still key gaps in terms of the assessment of interlinkages, trade-offs, and synergies between targets. Caiado et al. [23] presented a literature review and developed a framework to tackle the barriers and challenges for operationalizing and monitoring the implementation of the SDGs. Their review particularly focused on the application and linkage of the emerging SDGs with sustainability science 
and knowledge management aspects. Pizzi et al. [24] conducted a bibliometric investigation and systematic review on management research and the UN SDGs. They argued that researchers should pay particular attention to understanding how and to what extent the SDGs can strengthen business strategy and performance measurement. Most notably, recent reviews of the literature have shown that the SDGs could be considered possible strategic drivers for business-related research due to the face of their value relevance [25-27]. Beyond business strategies, sustainable development requires innovative product design strategies in a variety of contexts to support social, economic, and environmental responsibility across the entire value chain. However, due to the fact that the UN SDGs involve complex issues and heterogeneous domain knowledge, it is difficult for researchers to conduct a comprehensive review only in terms of a product design perspective. So far, there has been a lack of a literature review on how design strategies can assist designers, policy makers, and other stakeholders in implementing the SDGs.

Product designers would be responsible for delivering the SDGs, as they turn people's visions and attitudes into products and services to make life better. Moreover, any product or service requires material resources and ineluctably produces waste. If design is capable of imparting attitudes and values to people, it is also capable of translating the SDGs into the language and codes of products, services, systems, business models, and infrastructures. In this context, this study aimed to provide an overview of the literature through collecting and synthesizing evidence about existing design strategies, the purpose of which was to survey whether these strategies can adequately address the implementation of the UN SDGs. For structuring the scoping review and addressing the aim of this study, the research questions are outlined as follows:

- What ontologies exist relevant to design strategies toward the UN SDGs?

- What eligible design strategies already exist and to what extent are they suitable for addressing the SDGs?

- What gaps exist in the current body of design strategies in response to the SDGs?

The rest of this paper is structured as follows: Section 2 introduces the materials and methods. Section 3 presents the results of the scoping review. The discussion and concluding remarks, along with future research suggestions, are provided in Section 4.

\section{Materials and Methods}

This section provides background information and related works, including the scoping review method, design strategy and global sustainable development, and ontologies of the SDGs.

\subsection{Scoping Review Method}

A scoping review is an approach of research synthesis commonly used when a general research definition or definitive study procedure has not been well established [28]. It is used to evidence synthesis of domain knowledges, aiming to map the existing literature in a given field and provide an overview of the available research evidence without summarizing the specific research question [29,30]. Scoping reviews can help analyze and identify gaps in a body of knowledge and existing literature. According to Munn et al. [31], the scoping review framework includes: (1) determination of existing evidence types in a given field; (2) clarification of key concepts/definitions in the literature; (3) survey of how research was conducted on a certain topic/area; (4) examination of key characteristics relevant to a certain topic/area; (5) identification of knowledge gaps.

Scoping reviews help outline existing literature and relevant information sources, enabling researchers to explore the extent, range, and essence of research activity on a topic. They can be of particular use when the topic involves a complex and heterogeneous nature or has not thus far been comprehensively reviewed. Since the scoping review method can help to map broad topics and can offer a descriptive overview of the available materials without critically assessing individual studies or synthesizing evidence from different studies, compared with the systematic review method $[28,29,32]$, it is appropriate 
for use in this study to synthesize existing design strategies toward the implementation of the UN SDGs. Figure 1 presents the flow diagram of the scoping review process. The search strategy mainly includes academic research databases, such as Web of Science, ScienceDirect, JSTOT, SpringerLink, Taylor \& Francis Online, Wiley Online Library, as well as gray literature searches.
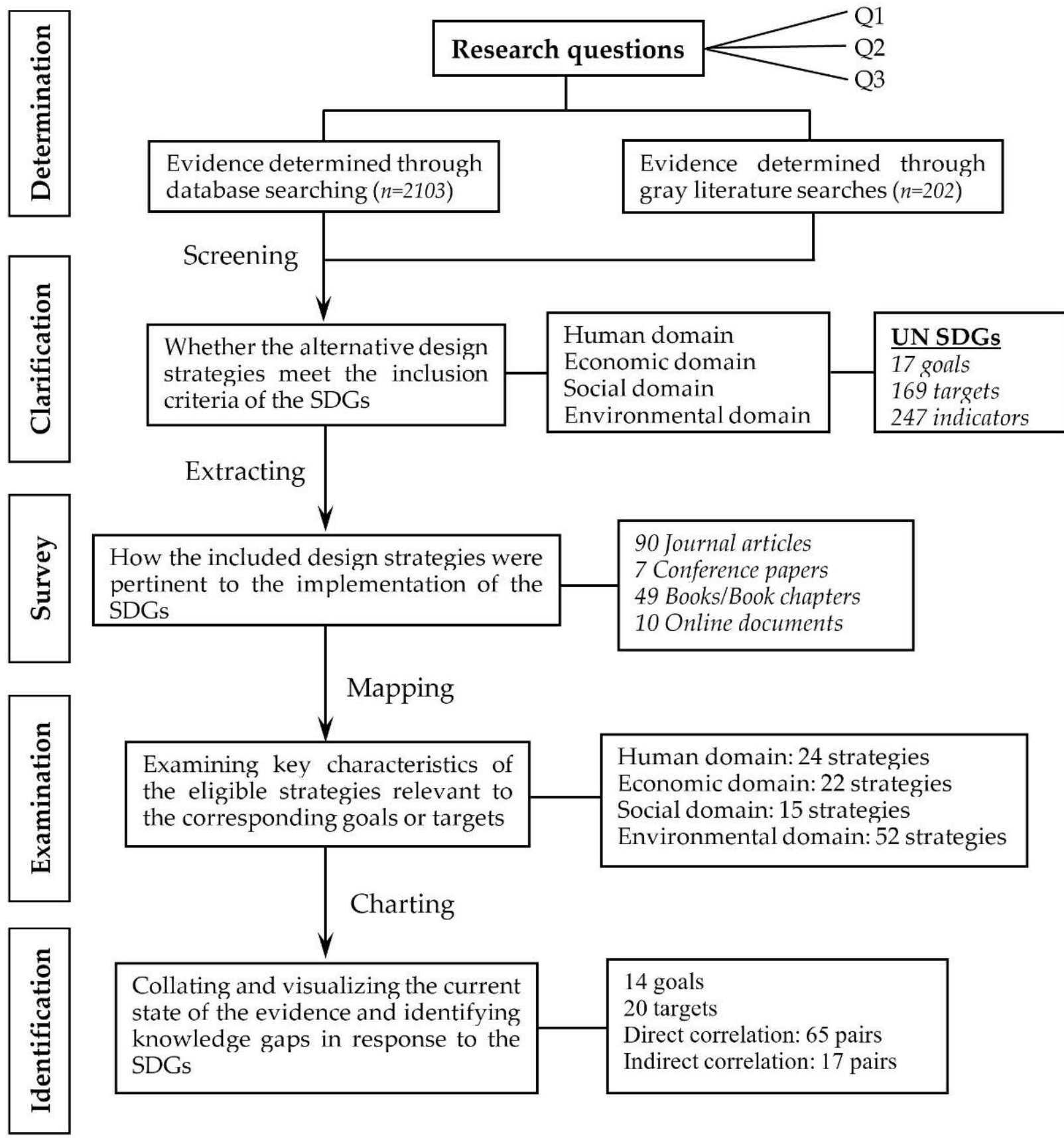

\section{Extracting}

How the included design strategies were
pertinent to the implementation of the
SDGs

90 Journal articles

7 Conference papers

49 Books/Book chapters

10 Online documents

\section{Mapping}

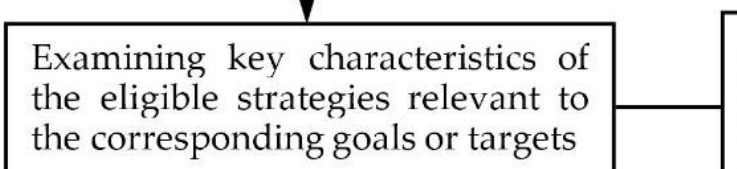

Human domain: 24 strategies

Economic domain: 22 strategies

Social domain: 15 strategies

Environmental domain: 52 strategies

\section{Charting}

Collating and visualizing the current state of the evidence and identifying knowledge gaps in response to the SDGs

14 goals

20 targets

Direct correlation: 65 pairs Indirect correlation: 17 pairs

Figure 1. Flow diagram of the scoping review process.

\subsection{Design Strategy and Global Sustainable Development}

The term design strategy refers to an integrated planning process that articulates business with design to guide designers with the goal for merging business objectives with creative solutions through creating innovative products and/or services. A good design strategy should provide designers with a clear vision and impact; give insight into what will make the product/service successful; guide the development path and support 
design decision making; incorporate other relevant disciplines into the entire process. Product design strategies tactically require various theories, methodologies, techniques, approaches, and/or guidelines to help achieve the product goal. Over the past few decades, they have evolved from the improvement of cost- and time-efficiency to the intervention of human concerns. Due to the dramatic growth of ecological implications and public awareness of environmental issues, environmental considerations have become a new industrial strategy for product design and development since the 1990s. How to integrate design, development, and processes into an effective methodology as well as develop environmentally conscious manufacturing and product recovery is of vital importance to industries [33,34]. Taking into consideration the three pillars of economic, social, and environmental dimensions, sustainable development has become strategically important to every life cycle aspect of product design, development, manufacturing, production, packaging, logistics, and even end-of-life (EoL) treatment. Incorporating product design with the concept of sustainability has been carried out for over three decades. However, due to the UN SDGs extending a previous sustainability agenda and comprising comprehensive domain-centric ontologies for reaching a consensus on their achievement, there is still a literature gap on how and what product design strategies can help achieve which of the SDGs. This remains to be addressed.

Figure 2 presents the significant milestones in global sustainable development. The Declaration of the UN Conference on the Human Environment (also known as the Stockholm Declaration), announced in 1972, was the first official document in international environmental policy to recognize the rights and responsibilities for ensuring a healthy environment. It marked a turning point for the global environment and development. The UNCED, also known as the Earth Summit/Rio Summit, held in Rio de Janeiro, Brazil, in 1992, was a new blueprint for international environmental action. Under the conference, the Rio Declaration reaffirmed the Stockholm Declaration and envisioned a global pact for environmental governance. The UN Programme of Action on the Sustainable Development of Small Island Developing States (also referred to as the Barbados Program of Action, BPoA) was introduced in 1994 as a policy document to address the vulnerabilities of economic, environmental, and social development facing islands as well as outlined a strategy seeking to mitigate those vulnerabilities. Beyond the sequential achievements of the Rio Summit and BPoA, the Millennium Summit took place at the United Nations Headquarters in 2000, adopted the UN Millennium Declaration that built on a decade of major UN conferences and summits to a series of time-bound targets. On the basis of this declaration, the Millennium Development Goals (MDGs) paved the way for a new vision of global sustainable development.

the future we want $\rightarrow$

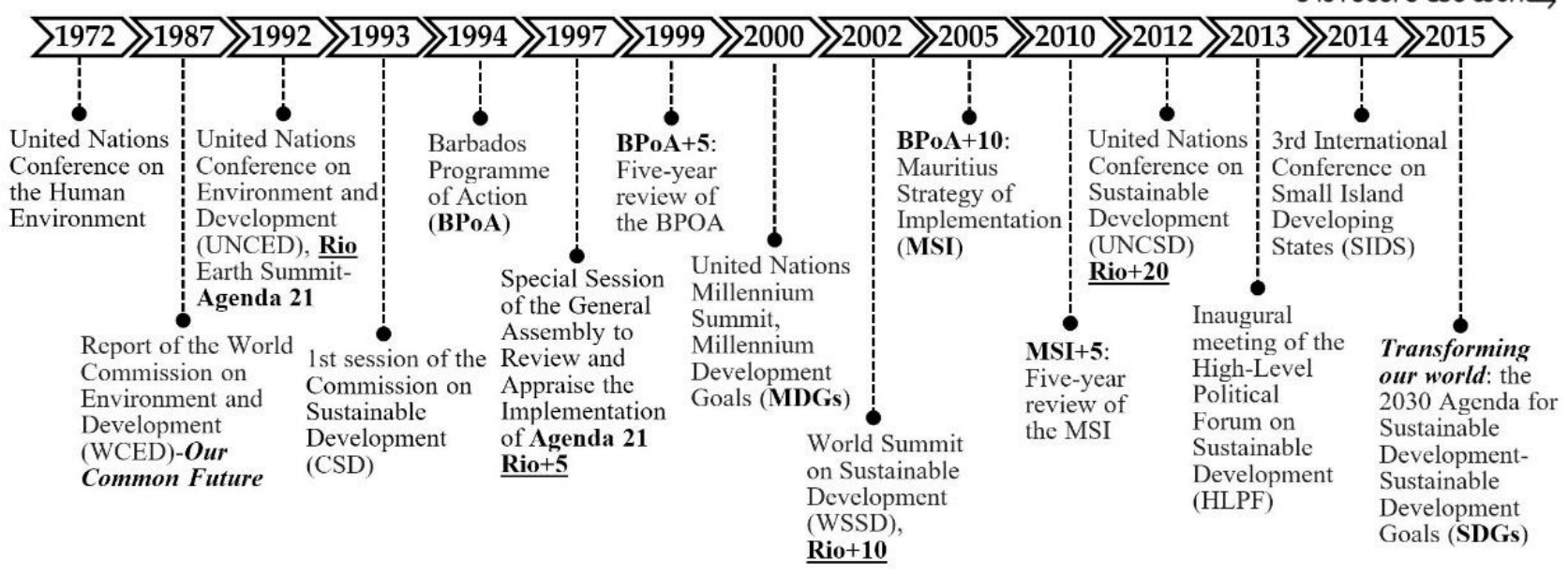

Figure 2. Significant milestones in global sustainable development. 
In 2015, the UN General Assembly published the historic document "Transforming our world: the 2030 Agenda for Sustainable Development". It is a plan of action with respect to people, planet, prosperity, peace, and partnership, aiming to achieve a better and more sustainable future for all by 2030. The 2030 Agenda comprises four sections: (1) a political declaration, (2) a set of 17 Sustainable Development Goals and 169 targets, (3) means of implementation, and (4) a framework for follow up and review of the Agenda. Although the SDGs draw heavily on the previous efforts given above, the implementation of these goals requires more ambition and comprehensiveness than the preceding attempts at global governance, making the SDGs an intriguing new global initiative in environmental policy and sustainable development [35].

\subsection{Ontologies of the Sustainable Development Goals (SDGs)}

The term ontology is an explicit specification of a conceptualization by where an ontology represents a systematic account of existence [32]. It can be used to help acquire knowledge and develop an understanding of a concept [36]. From the knowledge management perspective, Park and Ramaprasad [37] defined an ontology as a model or knowledge base used to construct and deconstruct the problem constituents in a logical, systematic, and meaningful manner to map and appraise current research in the domain. In this study, ontology is used to conceptualize the specification of the UN SDGs in order to map existing design strategies onto ontological domains.

According to the 2030 Agenda for Sustainable Development, the SDGs consist of 17 goals translated from the ambitions of administration; 169 targets which help to set-up a clear course of action toward the corresponding goals; 247 indicators used to measure progress toward reaching the targets [38]. The 17 goals and their corresponding descriptions are listed in Table 1. The original indicators include the global indicator framework for SDGs as contained in the Resolution A/RES/71/313. So far, the latest version of refinement E/CN.3/2021/2, Annex was approved by the 52nd Statistical Commission in March 2021. Of the 247 indicators, 8 and 4 indicators, respectively, repeat under two and three different targets, so that the actual number of indicators is 231. As of 29 March 2021, the updated tier classification contains 136 Tier I indicators (those which have a clear methodology and data gathered to support them), 107 Tier II indicators (those which have an established methodology but do not have regular data collection), and 4 indicators classified into both Tier I and Tier II [39].

Classification has been very useful for evidence syntheses, as it allows similarities and differences among interventions to be made explicitly. Various classifications of the SDGs have been presented from distinct perspectives, such as governance (Goals 16 and 17), economy (Goals 8-12), society (Goals 1-5), and planet (Goals 6, 7, and 13-15) [40]; dignity (Goals 1 and 5), people (Goals 2-4), planet (Goals 6 and 12-15), partnership (Goal 17), justice (Goal 16), and prosperity (Goals 7-11) [8]; efficient and sustainable resource use (Goals 2, 6, 7, and 12), earth system (Goals 13-15), human development goals (Goals 1, 3, 4, 5,8 , and 10), and good governance and infrastructure (Goals 9, 11, 16, and 17) [41]. The classification based on the triple bottom line (TBL or noted as 3Ps) was generally adopted by researchers [42,43]. Otherwise, according to the UN Environment Assembly of the UNEP, nearly half of the SDGs are directly environmental, and more than 86 targets involve environmental sustainability, with at least one in each of the 17 SDGs [44]. 
Table 1. List of the Sustainable Development Goals.

\begin{tabular}{|c|c|c|c|}
\hline Number & Goal & Description & Number of Target/Indicator \\
\hline 1 & No Poverty & Ending poverty in all its forms everywhere & 7 targets and 13 indicators \\
\hline 2 & Zero Hunger & $\begin{array}{l}\text { Ending hunger, achieving food security and } \\
\text { improved nutrition, and promoting } \\
\text { sustainable agriculture }\end{array}$ & 8 targets and 14 indicators \\
\hline 3 & Good Health and Well-Being & $\begin{array}{l}\text { Ensuring healthy lives and promoting } \\
\text { well-being for all at all ages }\end{array}$ & 13 targets and 28 indicators \\
\hline 4 & Quality Education & $\begin{array}{l}\text { Ensuring inclusive and equitable quality } \\
\text { education and promoting lifelong learning } \\
\text { opportunities for all }\end{array}$ & 10 targets and 12 indicators \\
\hline 5 & Gender Equality & $\begin{array}{l}\text { Achieving gender equality and empowering all } \\
\text { women and girls }\end{array}$ & 9 targets and 14 indicators \\
\hline 6 & Clean Water and Sanitation & $\begin{array}{l}\text { Ensuring availability and sustainable } \\
\text { management of water and sanitation for all }\end{array}$ & 8 targets and 11 indicators \\
\hline 7 & Affordable and Clean Energy & $\begin{array}{l}\text { Ensuring access to affordable, reliable, } \\
\text { sustainable and modern energy for all }\end{array}$ & 5 targets and 6 indicators \\
\hline 8 & $\begin{array}{l}\text { Decent Work and } \\
\text { Economic Growth }\end{array}$ & $\begin{array}{l}\text { Promoting sustained, inclusive and sustainable } \\
\text { economic growth, full and productive } \\
\text { employment and decent work for all }\end{array}$ & 12 targets and 16 indicators \\
\hline 9 & $\begin{array}{l}\text { Industry, Innovation, and } \\
\text { Infrastructure }\end{array}$ & $\begin{array}{l}\text { Building resilient infrastructure, promoting } \\
\text { inclusive and sustainable industrialization, and } \\
\text { fostering innovation }\end{array}$ & 8 targets and 12 indicators \\
\hline 10 & Reduced Inequalities & Reducing inequality within and among countries & 10 targets and 14 indicators \\
\hline 11 & $\begin{array}{l}\text { Sustainable Cities and } \\
\text { Communities }\end{array}$ & $\begin{array}{l}\text { Making cities and human settlements inclusive, } \\
\text { safe, resilient, and sustainable }\end{array}$ & 10 targets and 14 indicators \\
\hline 12 & $\begin{array}{l}\text { Responsible Consumption } \\
\text { and Production }\end{array}$ & $\begin{array}{l}\text { Ensuring sustainable consumption and } \\
\text { production patterns }\end{array}$ & 11 targets and 13 indicators \\
\hline 13 & Climate Action & $\begin{array}{l}\text { Taking urgent action to combat climate change } \\
\text { and its impacts }\end{array}$ & 5 targets and 8 indicators \\
\hline 14 & Life below Water & $\begin{array}{l}\text { Conserving and sustainably using the oceans, } \\
\text { seas, and marine resources for } \\
\text { sustainable development }\end{array}$ & 10 targets and 10 indicators \\
\hline 15 & Life on Land & $\begin{array}{l}\text { Protecting, restoring, and promoting sustainable } \\
\text { use of terrestrial ecosystems, sustainably } \\
\text { managing forests, combatting desertification, } \\
\text { and halting and reversing land degradation, and } \\
\text { halting biodiversity loss }\end{array}$ & 12 targets and 14 indicators \\
\hline 16 & $\begin{array}{l}\text { Peace, Justice, and } \\
\text { Strong Institutions }\end{array}$ & $\begin{array}{l}\text { Promoting peaceful and inclusive societies for } \\
\text { sustainable development, providing access to } \\
\text { justice for all, and building effective, accountable } \\
\text { and inclusive institutions at all levels }\end{array}$ & 12 targets and 24 indicators \\
\hline 17 & Partnerships for the Goals & $\begin{array}{l}\text { Strengthening the means of implementation and } \\
\text { revitalizing the global partnership for } \\
\text { sustainable development }\end{array}$ & 19 targets and 24 indicators \\
\hline
\end{tabular}

In the context of product design evolution, this study classified the 17 SDGs into four domains, namely, human (Goals 3, 5, and 17), economic (Goals 8-12), social (Goals 1, 2, 4, and 16), and environmental (Goals 6, 7, and 13-15). The human domain focuses on human performance, user satisfaction and accessibility, and usable and interactive quality of products, services, systems and/or environments. The economic domain aims to improve industrial productivity, profitability, and innovations. The social domain focuses on pro- 
moting social equality and inclusion and enhancing societal well-being. The environmental domain aims to minimize the unintended consequences of production and consumption processes in order to reduce the negative environmental impact. The ontology of the SDGs comprises four layers: 4 domains, 17 goals, 169 targets, and 247 indicators that aim to represent the knowledge structure of the UN SDGs for mapping of the corresponding design strategies. Since the ontology of the SDGs is an explicit claim with certain overlapping consensus, there exist intra-linkages within the 17 goals and interlinkages among the goal domains as shown in Figure 3. It is worth mentioning that the goals and their associated targets constitute a complicated network of interlinkages. Achieving one goal/target may contribute to achieving other goals/targets, whereas the achievement of one goal/target may conflict with the fulfillment of others. Such interlinkages are not constant and changeless but can be defined by causalities or by other types of relations/situations. To build the science-to-policy connections, the Institute for Global Environmental Strategies (IGES) developed the SDG Interlinkages Tool in 2017 and updated in 2019 (V3.0), which enables users to visualize the interlinkages among the targets as well as explore and download indicator-level data for the selected targets and countries (for more detailed information, please refer to the IGES website: https:/ / sdginterlinkages.iges.jp/index.html (accessed on 31 August 2021)).

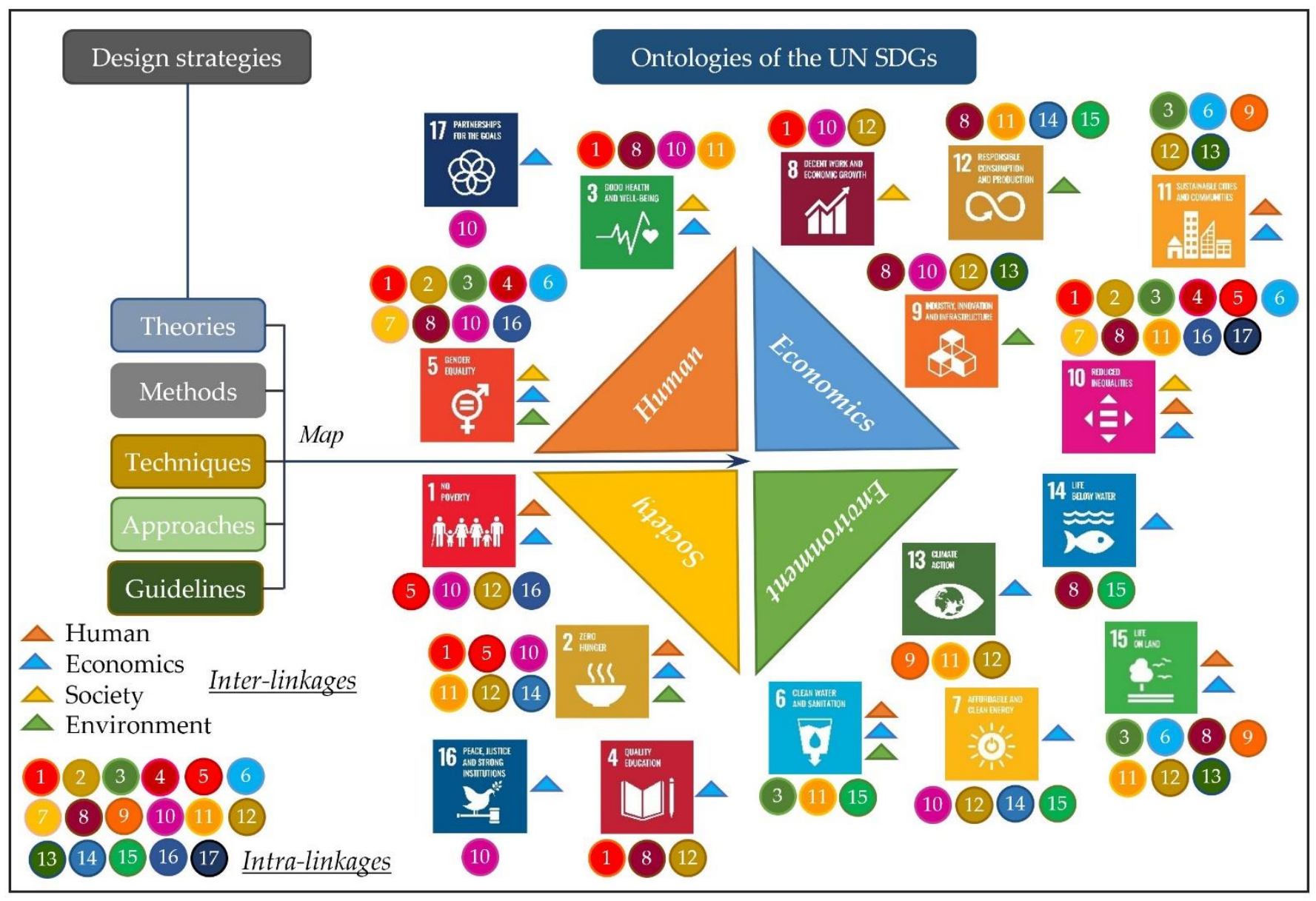

Figure 3. Ontologies of the UN SDGs for mapping of the corresponding design strategies.

\section{Results}

According to the scoping review, the results corresponding to the four domains are elaborated in the following subsections. 


\subsection{Design Strategies toward Human Domain}

The UN SDGs predominantly focus on human development through the implementations of economic, social, and environmental sustainability to achieve a better and more sustainable future for everyone. Human concerns have been systematically involved in product design since the mid-20th century. The term human factors and ergonomics (HFE) was developed as a scientific methodology for product, process, and system design to improve human performance, reduce human error, increase productivity, and enhance safety and comfort [45-47]. Human-centered design (HCD), defined by ISO 9241-210 and updated in 2019, is an approach to interactive system development aiming to make systems usable and useful by focusing on the users, their needs and requirements, and by applying HFE, and usability knowledge and techniques. This approach has the potential to contribute to strategic innovation and can help enhance effectiveness and efficiency, improve human well-being, user satisfaction, accessibility, and sustainability as well as counteract the possible adverse effects on human health, safety, and performance [48]. The term user-centered design (UCD) seems to be much more commonly used by the current design communities than that of HCD. HCD aims to address impacts on a number of stakeholders, while UCD focuses on those typically considered as users. However, in practice, these terms are often used synonymously [49]. These strategies can address the issues of Target 3.6, Target 4.a, Target 8.8, Target 9.1, and Target 11.2. To avoid repetition and redundancy, the descriptions of the corresponding targets mentioned above and afterward are listed in Appendix A, and the mapping correlations and mapping diagram are shown in Table 2 and Figure 4, respectively. Quality function deployment (QFD) was originally developed by Akao in the late 1960s as a method to transform qualitative customer requirements into quantitative parameters through deploying the functions forming quality and methods for achieving the design quality [50]. The term Kansei engineering (KE) was mentioned first by Yamamoto [51] and later founded by Nagamachi [52] as a customer-oriented technology for product design and development through translating customers' feelings into concrete product parameters. Axiomatic design (AxD), initially proposed by Suh in the late 1970s, is an approach using matrix methods to systematically analyze the transformation of customer needs into physical and process variables, functional requirements, and design parameters [53]. The design structure matrix (DSM, also known as dependency and structure modeling) is relevant to $\mathrm{AxD}$, which focuses on the elements of a complex system and how these elements relate to each other to support the management of complexity [54]. Moreover, adaptable design (AD) aims to develop adaptable products to satisfy the various requirements of customers [55], while empathic design (ED) focuses on the emotional relationship between customers and the product to achieve a better understanding of users' needs in the early design stage $[56,57]$. Through focusing on the human as well as capturing customers' feelings/emotions and requirements/needs, these strategies can be used to address Target 4.a, Target 8.2, Target 9.1, Target 9.b, and Target 11.2.

Table 2. List of mapping correlations.

\begin{tabular}{|c|c|c|c|}
\hline Item & Strategy & Direct Correlation & Indirect Correlation \\
\hline \multicolumn{4}{|c|}{ Design strategies toward human domain } \\
\hline A1 & $\begin{array}{l}\text { Human Factors and } \\
\text { Ergonomics (HFE) }\end{array}$ & \multirow{2}{*}{$\begin{array}{c}\text { Target 3.6; Target 4.a; } \\
\text { Target 8.8; Target 9.1; } \\
\text { Target } 11.2\end{array}$} & \\
\hline $\mathrm{A} 2 / \mathrm{A} 3$ & $\begin{array}{l}\text { Human-Centered Design } \\
\text { (HCD)/User-Centered } \\
\text { Design (UCD) }\end{array}$ & & \\
\hline
\end{tabular}


Table 2. Cont.

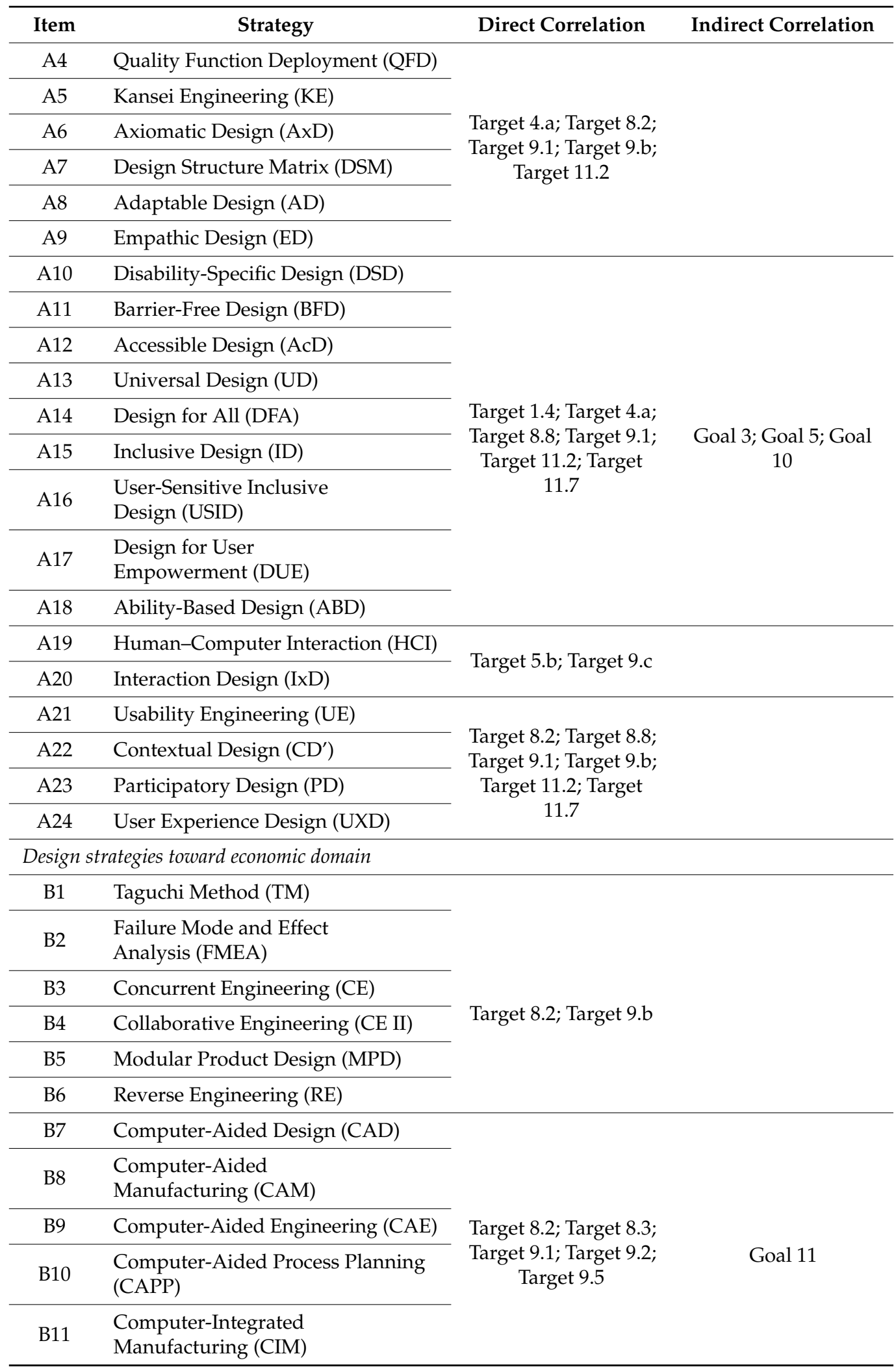


Table 2. Cont.

\begin{tabular}{|c|c|c|c|}
\hline Item & Strategy & Direct Correlation & Indirect Correlation \\
\hline B12 & Design for Manufacturing (DfM) & \multirow{10}{*}{$\begin{array}{l}\text { Target } 8.2 \text {; Target 9.2; } \\
\text { Target 9.5; Target 9.b }\end{array}$} & \\
\hline B13 & Design for Assembly (DfA) & & \\
\hline B14 & Design for Modularity (DfMo) & & \\
\hline B15 & Design for Availability (DfAv) & & \\
\hline B16 & Design for Cost (DfC) & & \\
\hline B17 & Design for Reliability (DfR) & & \\
\hline B18 & Design for Adaptability (DfAd) & & \\
\hline B19 & Design for Quality (DfQ) & & \\
\hline B20 & Design for Variety (DfV) & & \\
\hline B21 & Design for Variation (DfVa) & & \\
\hline $\mathrm{B} 22$ & $\begin{array}{l}\text { TRIZ (Theory of Inventive Problem } \\
\text { Solving) }\end{array}$ & \multicolumn{2}{|c|}{$\begin{array}{l}\text { Conflict-oriented problem solving } \\
\text { for innovations }\end{array}$} \\
\hline \multicolumn{4}{|c|}{ Design strategies toward social domain } \\
\hline $\mathrm{C} 1$ & Social Design (SD') & \multirow{8}{*}{ Goal 3; Goal 11} & \multirow{8}{*}{$\begin{array}{l}\text { Goal 1; Goal 2; Goal 4; } \\
\quad \text { Goal 5; Goal } 10\end{array}$} \\
\hline $\mathrm{C} 2$ & Socially Responsive Design (SRD II) & & \\
\hline $\mathrm{C} 3$ & Socially Responsible Design (SRD) & & \\
\hline $\mathrm{C} 4$ & Ethical Design (ED') & & \\
\hline C5 & Design Anthropology (DA) & & \\
\hline C6 & Design Activism (DAc) & & \\
\hline C7 & Design for Well-Being (DFW)j & & \\
\hline $\mathrm{C} 8$ & Social Product Development (SPD) & & \\
\hline C9 & Design for Social Inclusion (DfSIn) & \multirow{7}{*}{$\begin{array}{l}\text { Goal 3; Goal 8; Goal 9; } \\
\text { Goal } 11\end{array}$} & \multirow{7}{*}{$\begin{array}{l}\text { Goal 1; Goal 2; Goal 4; } \\
\text { Goal 5; Goal } 10\end{array}$} \\
\hline $\mathrm{C} 10$ & Design for Social Change (DfSC) & & \\
\hline C11 & Design for Social Impact (DfSIm) & & \\
\hline $\mathrm{C} 12$ & Social Impact Assessments (SIA) & & \\
\hline $\mathrm{C} 13$ & $\begin{array}{l}\text { Social Life Cycle } \\
\text { Assessments (SLCA) }\end{array}$ & & \\
\hline C14 & Design for Social Innovation (DfSI) & & \\
\hline $\mathrm{C} 15$ & ISO 26000 & & \\
\hline \multicolumn{4}{|c|}{ Design strategies toward environmental domain } \\
\hline D1 & End-of-Pipe (EoP) & \multirow{10}{*}{$\begin{array}{c}\text { Target 6.3; Target 7.3; } \\
\text { Target 8.4; Target 9.2; } \\
\text { Target 11.3; Target 9.4; } \\
\text { Target 11.6; } \\
\text { Goal 12; }\end{array}$} & \\
\hline $\mathrm{D} 2$ & Product Stewardship (PS) & & \\
\hline D3 & Regenerative Design (RD) & & \\
\hline $\mathrm{D} 4$ & Green Design (GD) & & \\
\hline D5 & Eco-Design (EcD) & & \\
\hline D6 & Cradle-to-Cradle Design (C2C) & & \\
\hline D7 & Sustainable Design (SD) & & \\
\hline D8 & Emotionally Durable Design (EDD) & & \\
\hline D9 & $\begin{array}{l}\text { Design for Sustainable } \\
\text { Behavior (DfSB) }\end{array}$ & & \\
\hline D10 & Biomimetic Design (BD) & & \\
\hline
\end{tabular}


Table 2. Cont.

\begin{tabular}{|c|c|c|c|}
\hline D11 & Ecological Product Design (EPD) & \multirow{17}{*}{$\begin{array}{c}\text { Target 6.3; Target 7.3; } \\
\text { Target 8.4; Target 9.2; } \\
\text { Target 9.4; Target 11.3; } \\
\text { Target 11.6; } \\
\text { Goal } 12\end{array}$} & \multirow{17}{*}{ Target 3.9; Target 14.1} \\
\hline D12 & Industrial Ecology (IE) & & \\
\hline D13 & Product Ecology (PE) & & \\
\hline D14 & $\begin{array}{l}\text { Environmentally Conscious } \\
\text { Design (ECD) }\end{array}$ & & \\
\hline D15 & Life Cycle Design (LCD) & & \\
\hline D16 & Design for Disassembly (DfD) & & \\
\hline D17 & Design for Reuse (DfRu) & & \\
\hline D18 & Design for Recycling (DfR) & & \\
\hline D19 & $\begin{array}{l}\text { Design for Maintenance/Design for } \\
\text { Maintainability (DfMa) }\end{array}$ & & \\
\hline $\mathrm{D} 20$ & Design for Supportability (DfSu) & & \\
\hline D21 & Design for Recovery (DfRc) & & \\
\hline D22 & $\begin{array}{l}\text { Design for Service/Design for } \\
\text { Serviceability (DfS) }\end{array}$ & & \\
\hline D23 & Design for Life Cycle (DfLC) & & \\
\hline D24 & Design for Environment (DfE) & & \\
\hline D25 & Design for Sustainability (D4S) & & \\
\hline D26 & Product-Service Systems (PSS) & & \\
\hline D27/D28 & $\begin{array}{l}\text { Circular Design (CD)/Circular } \\
\text { Product Design (CPD) }\end{array}$ & & \\
\hline D29 & Life Cycle Management (LCM) & \multirow{17}{*}{$\begin{array}{c}\text { Target 3.9; Target 6.3; } \\
\text { Target 7.3; Target 8.4; } \\
\text { Target 14.1; } \\
\text { Goal 9; Goal 11; Goal } \\
12\end{array}$} & \multirow{17}{*}{ Goal 13} \\
\hline D30 & $\begin{array}{l}\text { Life Cycle } \\
\text { Assessment/Analysis (LCA) }\end{array}$ & & \\
\hline D31 & Life Cycle Costing (LCC) & & \\
\hline D32 & $\begin{array}{l}\text { Life Cycle Sustainability Analysis } \\
\text { (LCSA) }\end{array}$ & & \\
\hline D33 & Life Cycle Inventory Analysis (LCI) & & \\
\hline D34 & $\begin{array}{l}\text { Life Cycle Impact } \\
\text { Assessment (LCIA) }\end{array}$ & & \\
\hline D35 & Life Cycle Engineering (LCE) & & \\
\hline D36 & $\begin{array}{l}\text { Screening Life Cycle } \\
\text { Modelling (SLCM) }\end{array}$ & & \\
\hline D37 & BS 8887-3 (2018) & & \\
\hline D38 & UNE 150,008 (2008) & & \\
\hline D39 & IEC 62,430 (2019) & & \\
\hline D40 & ISO 14,006 (2020) & & \\
\hline D41 & ISO 14,040 series & & \\
\hline D42 & ISO 14,091 (2021) & & \\
\hline D43 & $\begin{array}{l}\text { Environmentally Responsible } \\
\text { Product Assessment Matrix (ERPA) }\end{array}$ & & \\
\hline D44 & MECO Method & & \\
\hline $\mathrm{D} 45$ & Life Cycle Design Strategy (LiDS) & & \\
\hline
\end{tabular}


Table 2. Cont.

\begin{tabular}{cl}
\hline D46 & EcoCompass (EcC) \\
\hline D47 & EcoDesign Checklist (EcDC) \\
\hline D48 & MET-Matrix \\
\hline D49 & $\begin{array}{l}\text { Product Ideas Tree } \\
\text { (PIT) Diagram }\end{array}$ \\
\hline D50 & STRETCH \\
\hline D51 & Eco-Indicators (Eci) \\
\hline D52 & Ecodesign Pilot (EcDP) \\
\hline
\end{tabular}

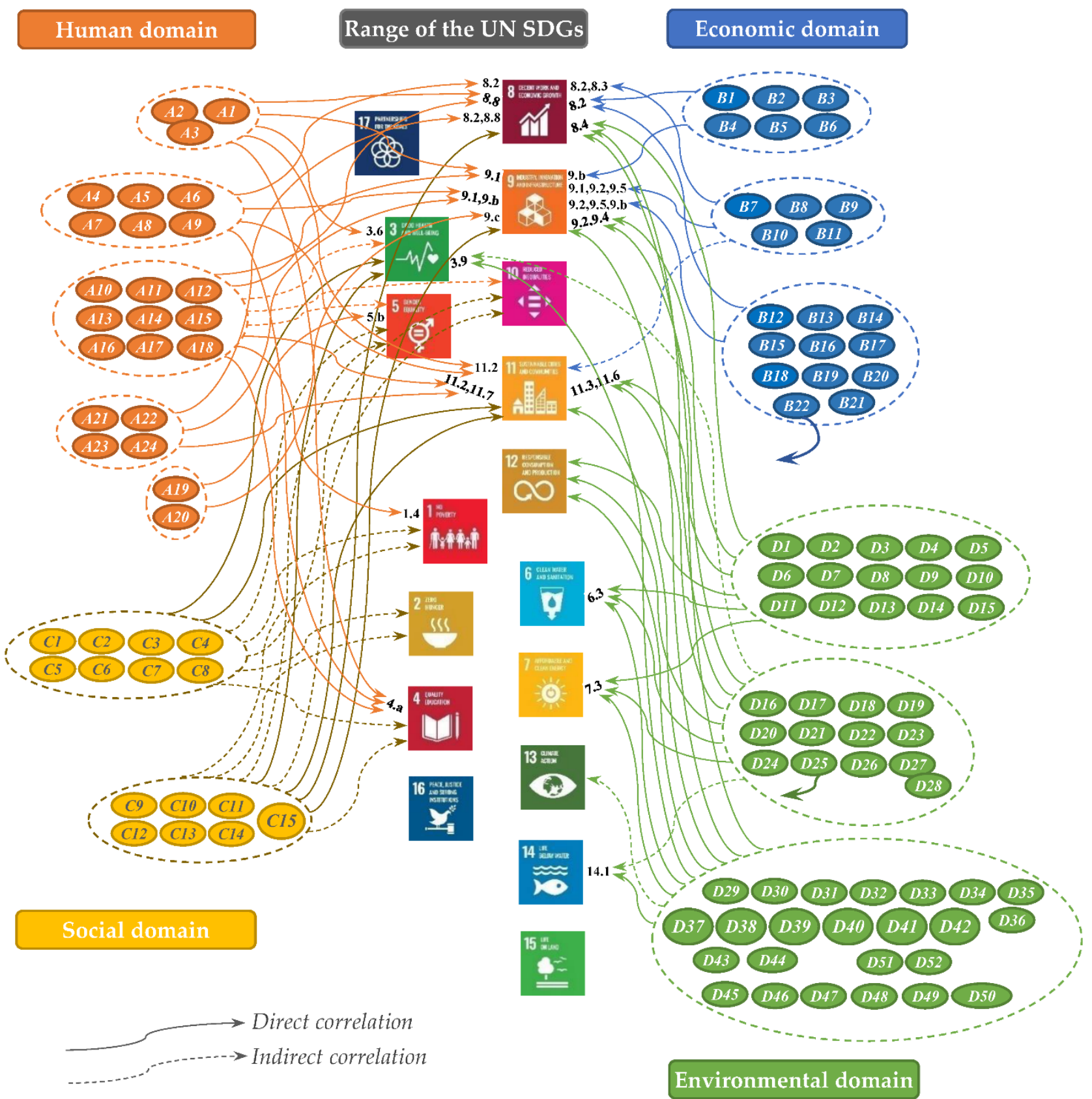

Figure 4. Mapping from the 4 domains of design strategies to the range of SDGs. 
There have been significant social changes concerning human rights and civil consciousness since the mid-20th century, turning societal attention to disadvantaged minorities in particular. Beyond disability-specific design (DSD), barrier-free design (BFD), and accessible design (AcD), universal design (UD) is an approach to creating everyday products and environments that are usable by all people to the greatest extent possible, regardless of age, gender, or ability, without the need for adaptation or specialized design [58]. The seven principles of UD (equitable use, flexibility in use, simple and intuitive use, perceptible information, tolerance for error, low physical effort, and size and space for approach and use) allow for the design of products and environments to meet the needs of potential users with a wide variety of characteristics in a wide range of situations [59]. Similar approaches, such as design for all (DFA) and inclusive design (ID), are also available in the literature [60]. Otherwise, user-sensitive inclusive design (USID) aims to understand disabled users and their specific needs [61]. Design for user empowerment (DUE) underlines the importance of user participation in the design process including those users with disabilities [62]. Ability-based design (ABD) encourages designers to focus on users' abilities to make the system efficient and adaptable [63]. Although there is no absolute consensus among these approaches, all of them recognize the essence of human diversity and social inclusion and highlight the importance of equal use of products, services, systems, and environments. These strategies can help to ensure the achievement of Target 1.4, Target 4.a, Target 8.8, Target 9.1, Target 11.2, and Target 11.7. The connotation and denotation of these strategies also correspond to the achievement of Goal 3, Goal 5, and Goal 10.

The emerging information age has brought about a new product design paradigm since the late 20th century. Beyond interacting with physical entities, human-computer interaction (HCI) explores the design and use of computer technology focused on the interaction between humans and computers [64]. Interaction design (IxD) assists designers in creating interactive digital products, environments, systems, and services [65]. These two strategies can help enhance the use of information and communications technology (ICT) to promote the empowerment of women (Target 5.b) and increase access to ICT and provide universal and affordable access to the Internet (Target 9.c). Usability is one of the core issues in $\mathrm{HCI}$, defined as "the extent to which a system, product, or service can be used by specified users to achieve specified goals with effectiveness, efficiency, and satisfaction in a specified context of use" [66]. Nielsen [67] developed usability engineering (UE) as a method to use throughout a product design process that ensures designers take into consideration the barriers to learnability, efficiency, memorability, error-free use, and subjective satisfaction before developing the product. Contextual design $\left(\mathrm{CD}^{\prime}\right)$ provides methods to collect data relevant to the product via field studies, interpret and consolidate the data in a structured way, apply the data to prototyping product and service concepts, and refine these concepts with users iteratively [68]. Empathic design (ED) assists designers in analyzing and applying information gleaned from observation in the field to help identify the users' underlying needs [69], whereas Participatory Design (PD) entails user participation for work practice based on the argument that users should be involved in designs [70]. The term user experience was coined by Norman in the early 1990s [71]. User experience design (UXD) aims to develop artifacts that allow users to meet their needs in an effective, efficient, and satisfying manner. It draws from design methods, such as HCI and UCD, and includes elements from similar disciplines such as IxD, usability, information architecture and user research [72,73]. The abovementioned strategies highlight the necessity of understanding users as well as meeting their needs, which can be applied to developing both physical and digital products/services/systems. Through improving the usable and interactive quality, these strategies can address the issues of Target 8.2, Target 8.8, Target 9.1, Target 9.b, Target 11.2, and Target 11.7. 


\subsection{Design Strategies toward Economic Domain}

Design strategies toward the economic domain can look backward to the history of the Industrial Revolution in the mid-18th century. Individual manual labor was replaced by mechanical production to boost the development of the industrial economy. The strategies of design for mechanical production and design for mass production ushered in a new era of mass production and mass consumption [74]. Increasing global competition associated with the changing economic environment, meant industries must focus on cost reduction and efficiency improvement to achieve higher levels of productivity and profitability. The Taguchi method (TM) was proposed by Taguchi in the 1950s, which aims to improve product and process quality throughout the entire product life cycle in a parametric design manner $[75,76]$. The failure mode and effect analysis (FMEA) was developed in the early 1960s as a systematic approach for dealing with potential product failure problems [77]. It can be used to analyze postulated component failures as well as identify the resultant effects on products or system operation. In addition to quality improvement and failure avoidance, how to rapidly develop a product and launch it on the market has been a crucial issue since the 1980s. Industry and academia have made great efforts to develop new approaches that focus on reducing lead time for product design and development through parallelizing or subdividing all possible activities in overall product design and development processes. Concurrent engineering (CE) is defined as a systematic approach to the integrated design of products and their related processes simultaneously, enabling designers to consider all elements of the product life cycle in the early design stage including quality, cost, schedule, and user requirements [78]. CE and collaborative engineering (CE II) have emerged as new paradigms instead of traditional sequential engineering (SE) with significant impact on the development of products and processes $[79,80]$. Modular product design (MPD) aims to reduce complexity through subdividing complex products and systems into components instead of as an amalgamated whole [81]. Reverse engineering (RE) refers to a process or an approach in which products and systems are deconstructed to extract design information from them, enabling designers to analyze how a component was designed so that they can recreate it rapidly [82]. These strategies can assist designers in achieving Target 8.2 and Target 9.b. On the other hand, various design techniques have been developed in response to the extensive application of computer and information technologies in products and production processes, such as computer-aided design (CAD), computer-aided manufacturing (CAM), computer-aided engineering (CAE), computer-aided process planning (CAPP), and computer-integrated manufacturing (CIM) [83-85]. The employment of these techniques makes product design more powerful and efficient and, thus, can help address Target 8.2, Target 8.3, Target 9.1, Target 9.2, and Target 9.5. Such computer-aided techniques can also be beneficial to make cities and human settlements inclusive, safe, resilient, and sustainable (Goal 11) through efficient and reliable design and planning.

Design for $\mathrm{X}(\mathrm{DfX})$ refers to a set of strategies adopted by design communities to achieve specific engineering objectives through improving an $\mathrm{X}$ property of the product/system [86-88]. These strategies include design for manufacturing (DfM) [89], design for assembly (DfA) [90], design for modularity (DfMo) [91], design for availability (DfAv) [92], design for cost (DfC) [93], design for reliability (DfR) [94], design for adaptability (DfAd) [95], design for quality (DfQ) [96], design for variety (DfV) [97], and design for variation (DfVa) [98]. The family of DfX comprises methods, guidelines, and standards to develop products at the conceptual design phase [99]. They are used as an integral part of the product design process to create products with higher quality, lower cost, and shorter development cycles. Such improvements can help achieve Target 8.2, Target 9.2, Target 9.5, and Target 9.b. The implementation of the UN SDGs inevitably involves trade-offs and contradictions. Of the various design strategies, TRIZ (theory of inventive problem solving) is a unique one that can provide designers with the processes of repeatability, predictability, and reliability due to the fact of its structural and algorithmic characteristics. It was initially developed by Althuller and his colleagues in the mid-1940s. TRIZ 
is a systematic and knowledge-based methodology for designers to analyze inventive problems and further resolve them in a strategy-directed manner [100]. It has been extensively employed by both academia and industry over the past half century [101], not only in traditional engineering fields for product development [102] but also in business and management [103], service design [104], maintenance [105], education [106], building industry [107], renewable energy [108], green supply chain [109], eco-design [110], eco-innovation [111]/eco-improvement [112], cleaner production [113], sustainable innovation [114], and even gene selection for cancer classification [115]. Due to the fact of its excellent performance and broad applicability, TRIZ methodology has great potential to address most of the SDG issues relevant to conflict-oriented problem solving for innovations.

\subsection{Design Strategies toward Social Domain}

Social responsibility has been a recurring topic for design communities over the past few decades. Papanek [116] indicated that design is an attitude of constant awareness in professional practice to avoid producing excessive and useless products. He argued that design should not only serve the people (both healthy and disabled people) but also serve the protection of the limited resources of the planet we live on. Whiteley [117] also pointed out the dilemma of unsound consumerism and highlighted that good design should consider a product's social usefulness and environmental effects. In addition to promoting accessible and usable products, services and environments for everyone, social design $\left(\mathrm{SD}^{\prime}\right)$ refers to design for society and with society that seeks for a new networking of the individual, civil society, and government in response to the global economic growth and its consequences for humans and the environment [118]. Socially responsive design (SRD II) aims to improve equitable arrangements among stakeholders to ensure the effective delivery of design for social change and to make proper contributions to addressing societal goals in a sustainable way [119], while SRD responds to all stakeholders and investigates the consequences of design that positively impacts on societal aspirations and expectations, health, and lifestyle [120]. Ethical design (ED') emphasizes that designers should have a responsibility to take ethical requirements of product design into account through conducting risk and ethical analyses and countermeasures of the designed products [121]. Design anthropology (DA) comprises both business sense and social responsibility to develop a product through conducting with users or potential users for articulating the everyday practices, symbolic meanings, and forms of sociality with the product [122]. Design activism (DAc) highlights the strength of design for social and environmental progress that positively impacts our living and working, and challenges and reinvigorates design praxis in sustainable ways [123]. Moreover, design for well-being (DFW) focuses on improving the individual and societal well-being and happiness of people through the development and application of design research [124]. Social product development (SPD) refers to an emerging engineering approach and design processes, encompassing such phenomena as crowdsourcing, open innovation, collective intelligence, and mass collaboration [125,126]. These strategies can be applied to ensuring the achievement of Goal 3 and Goal 11. Beyond product functionality and utility, these strategies also imply that designers should pay more attention to other sustainable issues, such as improving poverty (Goal 1), hunger (Goal 2), education and gender equality (Goal 4 and Goal 5), and even reducing inequalities (Goal 10).

Another type of DfX is available in the social domain. Inspired by inclusive design (ID), design for social inclusion (DfSIn) recognizes the need for co-design with people from marginalized segments of the population who act as design partners in efforts to create environmental, cultural, economic, and social sustainability [127]. Design for social change (DfSC) entails the adoption of various strategies toward human-centered innovation to bring positive results, especially in marginalized communities, where living conditions can be improved in many aspects [128]. DfSIm aims at the practice of interrogation systems to clarify opportunities for change by giving voice to those who have been disenfranchised 
or marginalized by design [129]. Pack et al. [130] found that social impact assessments (SIAs) and social life cycle assessments (SLCAs) are two of the most common techniques for assessing social impact. SIAs can be used to analyze, monitor, and manage the intended and unintended social consequences of planned interventions [131], while SLCAs can be applied to understanding social issues arising in the value chains of products and services [132]. Design for social innovation (DfSI) aims to produce meaningful social innovation through dealing with all kinds of social change toward sustainability [133,134]. On the other hand, corporate social responsibility (CSR) is a management concept whereby enterprises take social and environmental responsibility in their business operations and interactions with their stakeholders [135,136]. The International Organization for Standardization (ISO) also launched a guidance integrating international expertise on the concept of the social responsibility to harmonize the socially responsible behavior of enterprises at international level [137]. The abovementioned strategies can be useful for ensuring the achievement of Goal 3, Goal 8, Goal 9, and Goal 11. In a broader sense, design has the potential to trigger and support social change so that it should focus on the most important challenges and complex social problems we are facing such as reducing poverty (Goal 1), hunger (Goal 2), inequality (Goals 5 and 10), and ensuring inclusive and equitable quality education (Goal 4). Although these design strategies perhaps cannot directly address such specific goals, they can be used to assist designers in connecting innovative design practices with the goals, and further exploring the know-how behind designing new products/services to help people shape a positive future.

\subsection{Design Strategies toward Environmental Domain}

Design strategies addressing ecological challenges and sustainable development issues typically fall under the umbrella of various concepts. End-of-pipe (EoP) approaches are regarded as pollution control strategies through physically separating pollutant treatment from production processes to minimize the potential environmental damage caused by untreated pollutants [138]. Since the mid-20th century, the reaction of humans to environmental degradation has changed from EoP treatment to a focus on prevention strategies. This essentially means that research and innovation efforts have shifted from the passive depollution of systems to the positive pollution management at source $[139,140]$. Product stewardship (PS) attempts to minimize environmental impact at one stage of a product's life cycle which may actually increase the impact at other life cycle stages $[141,142]$. Regenerative design (RD) is defined as a process-oriented system approach that envisions a community based on the value of living within the limits of available energy and material resources without environmental degradation [143]. On the other hand, green consumerism emerged as an ecopedagogical issue in the late 1980s, influencing human activities, societies, and even an interdisciplinary reflection on environmental ethics. green design (GD) treats environmental attributes as product design objectives by introducing the principle of the 3Rs: reducing, reusing, and recycling [144], while eco-design (EcD) integrates environmental considerations into the product design and development process [145]. Cradle-to-cradle design (C2C) presents an alternative design concept based on the strategies of eco-efficiency and zero emission to create products and systems in a positive relationship with ecological and economic benefits [146]. Sustainable design (SD) intends to reduce negative environmental impact completely through skillful, sensitive design, which implies that $\mathrm{SD}$ requires renewable resources and innovation to minimalize the impact of the environment and connect people with the natural environment [147]. The transition from GD, EcD, and $\mathrm{C} 2 \mathrm{C}$ to $\mathrm{SD}$ steady broadens the scope of ecology and design in theory and practice. It also shifts the design focus from mass production and mass consumption to sustainable consumption and production (SCP) patterns. Emotionally durable design (EDD) underlines the importance of consumers' behavioral drivers toward $\mathrm{SD}$ as well as develops strategies to increase resource productivity and reduce waste by elongating the lifespan of products [148]. Design for sustainable behavior (DFSB) is an emerging strategy under the theme of $\mathrm{SD}$, aiming to examine how design can be used to 
affect user behavior toward more sustainable practices [149]. Design stages have been recognized as a key phase in a product's life cycle for the sustainability implementation [150]. Biomimetic design (BD) facilitates the design by taking inspiration from nature to design as well as transferring biological mechanisms into design concepts to achieve innovation and sustainability [151], while ecological product design (EPD) integrates environmental considerations into product design in advance rather than an afterthought [152]. Arising out of an ecological metaphor, industrial ecology (IE) refers to a framework for product and process design to achieve the strategic implementation of SCP [153], while product ecology (PE) is a theoretical framework to describe how products evoke social behavior, and an approach for conducting qualitative design research with the goal of understanding the interactions between people and products [154]. Environmentally conscious design (ECD) aims to ensure superior environmental performance of products through identifying environmentally friendly design alternatives [155,156]. Life cycle design (LCD) considers entire life cycle phases of products in the early design stage to fulfill the environmental requirements [157]. The abovementioned strategies can be used to help achieve Target 6.3, Target 7.3, Target 8.4, Target 9.2, Target 9.4, Target 11.3, Target 11.6, and Goal 12.

There are also some DfX approaches available to address ecological issues, such as design for disassembly (DfD) [158], design for reuse (DfRu) [159], design for recycling (DfR) [160], design for maintenance [161]/design for maintainability (DfMa) [162], design for supportability (DfSu) [163], design for recovery (DfRc) [164], and design for service [165]/design for serviceability (DfS) [166]. Moreover, design for life cycle (DfLC) broadens the ecological perspective beyond the reduction, elimination, and prevention of waste, which comprises the entire product life cycle from initial conceptual design, through use phase, to EoL of the product [167]. Design for environment (DfE) also takes a life cycle approach to product design and development, considering such novel concerns as environmental consequences, and human health and safety [168]. A notable strategy for implementing sustainability is design for sustainability (D4S), which builds on the work of $\mathrm{EcD}$ to comprise social, economic, and environmental concerns and outlines methodologies for making sustainable improvements to products by applying lifecycle thinking components [169]. Ceschin and Gaziulusoy [170] provided a systematic overview of the D4S domain and found that the D4S has increasingly evolved from a technical and product-centric focus to an extensive system level change in which sustainability is perceived as a socio-technical challenge. Accompanied by the growing service-centered economy, the strategy of Product-Service Systems (PSS), motivated by customers, shifts the business focus from just physical product design and selling, to a system offering which combines services with the product to fulfill customers' needs without increasing environmental impact $[171,172]$. PSS particularly fits with the SDG strategies as it can allow product lifetime extension, intensive use of products, and minimization of resource consumption [173,174]. Beyond the strategy of DfR, circular design (CD) [175] or circular product design (CPD) [176] focuses on minimizing the use of primary raw materials to curtail a value loss embedded in the product by keeping them in a closed-loop circulation mode. Through effective elimination, reduction, minimization, and prevention of the life cycle management and implementation, these strategies can be used to address Target 6.3, Target 7.3, Target 8.4, Target 9.2, Target 9.4, Target 11.3, Target 11.6, and Goal 12. They would also be helpful in addressing Target 3.9 and Target 14.1.

Various life cycle approaches have been employed to assist designers in assessing the performance of sustainability [177], such as life cycle management (LCM) [178], life cycle assessment [179]/life cycle analysis (LCA) [180], life cycle costing (LCC) [181], life cycle sustainability analysis (LCSA) [182], life cycle inventory analysis (LCI) [183], life cycle impact assessment (LCIA) [184], life cycle engineering (LCE) [185], and screening life cycle modeling (SLCM) [186]. There are many guidelines and standards to provide solutions and help achieve benefits for sustainable performances, such as BS 8887-3:2018 for guiding to choosing an appropriate EoL design strategy [187]; UNE 150008:2008 for environmental risk analysis and assessment [188]; IEC 62430:2019 describing principles, specifying re- 
quirements, and providing guidance for organizations to integrate ECD into their product design and development [189]; ISO 14006:2020 that provides guidelines for incorporating EcD [190]; ISO 14,040 series for dealing with LCA [191]; ISO 14091:2021 that gives guidelines for assessing the risks related to the potential impacts of climate change [192]. Other simplified LCA methods include ERPA (environmentally responsible product assessment)matrix and MECO (materials, energy, chemicals, and others) method [193]. Some visualization tools and checklists are also available for use in product design processes to help achieve eco-innovation through identifying potential environmental impacts, including the life cycle design strategy (LiDS) wheel [194], EcoCompass (EcC) [195], EcoDesign Checklist (EcDC) [196], MET (material, energy, and toxicity)-matrix [146], product ideas tree (PIT) diagram [197], the methodology of selection of strategic environmental challenges (STRETCH) [198]. Otherwise, eco-indicators (Eci) provide designers with easy-to-use tools to develop products, taking into consideration the recycling quotas, energy consumption, amount of material used, and waste produced in the early design stage [199]. EcoDesign Pilot (EcDP) can be used as a tool to investigate, discover, and optimize products for achieving sustainable development [200]. These strategies can provide effective information to help achieve Target 3.9, Target 6.3, Target 7.3, Target 8.4, and Target 14.1. They can also be helpful to the implementation of Goal 9, Goal 11, and Goal 12 and, in a broad sense, might have a potential implication for the mitigation of climate change and its impact on the environment (Goal 13).

\section{Discussion and Concluding Remarks}

Since the UN SDGs involve complex topics and the heterogeneous nature of domain knowledge, it is difficult for researchers to conduct a comprehensive review only in terms of the product design perspective. This study combined the conception of ontology with the scoping review method and presented a literature review on how design strategies can potentially be employed to achieve certain aspects of the SDGs, so far lacking in the scientific literature. According to the research questions, the specification of the UN SDGs was conceptualized as the domain ontology to map existing design strategies onto the ontological domains. Based on the four pillars of human, economic, social, and environmental domains, more than 110 design strategies were collected and synthesized as existing evidence in the literature to survey how they would be pertinent to help address the implementation challenges of the SDGs. As a whole, the existing design strategies have a potential for use toward Goal 8 (Decent Work and Economic Growth), Goal 9 (Industry, Innovation and Infrastructure), Goal 11 (Sustainable Cities and Communities) as well as Goal 12 (Responsible Consumption and Production). To some extent, the corresponding strategies can be workable to Goal 3 (Good Health and Well-being), Goal 4 (Quality Education), Goal 6 (Clean Water and Sanitation), and Goal 7 (Affordable and Clean Energy), even if they are not immediately obvious. Despite the lack of substantial evidence of effectiveness, goals where the design strategies corresponded to their contextual implications include Goal 1 (No Poverty), Goal 2 (Zero Hunger), Goal 5 (Gender Equality), and Goal 10 (Reduced Inequalities). Although Goal 13 (Climate Action), Goal 14 (Life below Water), and Goal 15 (Life on Land), in particular, are regarded as environmental issues, there has been little evidence to support the effective implementation in the context of applying these design strategies.

In addition, there has been a gap in the current body of design strategies in response to Goal 16 (Peace, Justice, and Strong Institutions) and Goal 17 (Partnerships for the Goals). This is mainly because they require more political consensus than practical operation that design strategies can manage. Of the various design strategies, TRIZ has great potential to address most of the SDG issues relevant to conflict-oriented problem solving for innovations, while D4S is a notable strategy that not only directly links the term "design" with the goal "sustainability" in its literal sense but also equally underlines social, economic, and environmental sustainability. It is worth noting that there has been relatively little concrete evidence on how the corresponding design strategies can directly address the 
social development issues of the SDGs. This is due primarily to the characteristics of social issues, which are not static situations but changes over time and space and have different impacts on different individuals. Although there has been an increasing interest in social responsibility in both research and practice, most of it has focused on the environmental dimension of responsibility [201]. Rocha et al. [202] also indicated that the social dimension of D4S is not well established and has yet to be tackled in a non-systemized way. Hence, there is still room for development in this research theme. The scoping review results imply that policy makers should make more effort to reach a consensus on the issues of Goal 16 and Goal 17, while designers could pay more attention to the social development issue of the SDGs. The implementation and achievability of Goal 13, Goal 14, and Goal 15 still need a progressive action by design communities as well as by stakeholders around the world.

Similar to other studies, scoping reviews have risk of bias from different sources even if crucial risk assessment of the bias is not considered mandatory [30]. The important limitation lies in the fact that this scoping review has only considered the context of evidence but did not formally evaluate the quality of evidence in the literature. Research on the 2030 Agenda for Sustainable Development is still in progress. Since the importance of empathy, collaboration, and non-linear problem solving has raised attention to academia and industry, there has been growing interest in applying design thinking (DT) to sustainability research and practice [203-205]. This can be a potential research direction. In conclusion, this is the first study that has presented comprehensive evidence for coupling the existing design strategies with the implementation of the SDGs. Academically, this study offers a starting point for researchers to explore how design has been contributing to the sustainability goals. In practice, this work contributes to existing knowledge of the design discipline by providing methodological guidance for researchers and practitioners to conduct further research and practice on the UN SDGs. In addition to the 17 goals and 169 targets, the 2030 Agenda comprises a total of 247 indicators to map and assess the achievement and implementation of the corresponding goals/targets. Extending the scoping review study, future research could focus on developing a sustainability assessment method associated with a condensed set of indicators to evaluate the quality of evidence for the available design strategies.

Funding: This research was funded by Ministry of Science and Technology, Taiwan, grant number MOST 109-2221-E-214-021.

Acknowledgments: The author would like to thank the Ministry of Science and Technology, Taiwan, for financially supporting this research under grant number MOST 109-2221-E-214-021.

Conflicts of Interest: The author declares no conflict of interest.

\section{Appendix A}

\begin{tabular}{cl}
\hline Target & \multicolumn{1}{c}{ Description } \\
\hline Target 1.4 & $\begin{array}{l}\text { All men and women, in particular the poor and the vulnerable, having equal } \\
\text { lefts to economic resources, as well as access to basic services and appropriate } \\
\text { new technology }\end{array}$ \\
\hline Target 3.6 & Reducing the number of global deaths and injuries from road traffic accidents \\
\hline Target 3.9 & $\begin{array}{l}\text { Reducing the number of deaths and illnesses from hazardous chemicals and air, } \\
\text { water and soil pollution and contamination }\end{array}$ \\
\hline Target 4.a & $\begin{array}{l}\text { Building and upgrading education facilities that are child, disability and gender } \\
\text { sensitive and providing safe, inclusive, and effective learning environments } \\
\text { for all }\end{array}$ \\
\hline Target 6.3 & $\begin{array}{l}\text { Improving water quality by reducing pollution, eliminating dumping and } \\
\text { minimizing release of hazardous chemicals and materials }\end{array}$ \\
\hline Target 7.3 & Improving energy efficiency \\
\hline
\end{tabular}




\begin{tabular}{|c|c|}
\hline Target & Description \\
\hline Target 8.2 & $\begin{array}{l}\text { Achieving higher levels of economic productivity through diversification, } \\
\text { technological upgrading and innovation }\end{array}$ \\
\hline Target 8.3 & Supporting productive activities, creativity, and innovation \\
\hline Target 8.4 & $\begin{array}{l}\text { Improving global resource efficiency in consumption and production, and } \\
\text { endeavoring to decouple economic growth from environmental degradation }\end{array}$ \\
\hline Target 8.8 & Promoting safe and secure working environments for all workers \\
\hline Target 9.1 & $\begin{array}{l}\text { Developing quality, reliable, sustainable and resilient infrastructure to support } \\
\text { economic development and human well-being with a focus on affordable and } \\
\text { equitable access for all }\end{array}$ \\
\hline Target 9.2 & Promoting inclusive and sustainable industrialization \\
\hline Target 9.4 & $\begin{array}{l}\text { Upgrading infrastructure and retrofitting industries to make them sustainable } \\
\text { with increased resource-use efficiency and greater adoption of clean and } \\
\text { environmentally sound technologies and industrial processes }\end{array}$ \\
\hline Target 9.5 & Upgrading the technological capabilities and encouraging innovation \\
\hline Target 9.b & $\begin{array}{l}\text { Supporting domestic technology development, research and innovation that } \\
\text { ensures industrial diversification and value addition to commodities }\end{array}$ \\
\hline Target 11.2 & $\begin{array}{l}\text { Providing access to safe, affordable, accessible and sustainable transport systems } \\
\text { for all, improving road safety and expanding public transport with special } \\
\text { attention to the needs of those in vulnerable situations, women, children, } \\
\text { persons with disabilities, and older persons }\end{array}$ \\
\hline Target 11.3 & Enhancing inclusive and sustainable urbanization \\
\hline Target 11.6 & $\begin{array}{l}\text { Reducing the adverse environmental impact of cities by paying special attention } \\
\text { to air quality and other waste management }\end{array}$ \\
\hline Target 11.7 & $\begin{array}{l}\text { Providing universal access to safe, inclusive and accessible, green and public } \\
\text { spaces, in particular for women and children, older persons, and persons } \\
\text { with disabilities }\end{array}$ \\
\hline Target 14.1 & $\begin{array}{l}\text { Preventing and reducing marine pollution of all kinds, in particular from } \\
\text { land-based activities }\end{array}$ \\
\hline
\end{tabular}

\section{References}

1. World Commission on Environment and Development. Our Common Future; Oxford University Press: Oxford, UK, 1987.

2. Conard, B.R. Some Challenges to sustainability. Sustainability 2013, 5, 3368-3381. [CrossRef]

3. Lomazzi, M.; Borisch, B.; Laaser, U. The Millennium Development Goals: Experiences, achievements and what's next. Glob. Health Action 2014, 7, 23695. [CrossRef]

4. McArthur, J.W.; Rasmussen, K. Change of pace: Accelerations and advances during the Millennium development goal era. World Dev. 2018, 105, 132-143. [CrossRef]

5. Orzes, G.; Moretto, A.M.; Ebrahimpour, M.; Sartor, M.; Moro, M.; Rossi, M. United nations global compact: Literature review and theory-based research agenda. J. Clean. Prod. 2018, 177, 633-654. [CrossRef]

6. Gupta, J.; Vegelin, C. Sustainable development goals and inclusive development. Int. Environ. Agreem. Politics Law Econ. 2016, 16, 433-448. [CrossRef]

7. Stafford-Smith, M.; Griggs, D.; Gaffney, O.; Ullah, F.; Reyers, B.; Kanie, N.; Stigson, B.; Shrivastava, P.; Leach, M.; O’Connell, D. Integration: The key to implementing the Sustainable Development Goals. Sustain. Sci. 2017, 12, 911-919. [CrossRef]

8. Leal Filho, W.; Azeiteiro, U.; Alves, F.; Pace, P.; Mifsud, M.; Brandli, L.L.; Caeiro, S.S.; Disterheft, A. Reinvigorating the sustainable development research agenda: The role of the Sustainable Development Goals (SDG). Int. Sustain. Dev. World Ecol. 2018, 25, 131-142. [CrossRef]

9. Salvia, A.L.; Leal Filho, W.; Brandli, L.L.; Griebeler, J.S. Assessing research trends related to Sustainable Development Goals: Local and global issues. J. Clean. Prod. 2019, 208, 841-849. [CrossRef]

10. Ospina-Forero, L.; Castañeda, G.; Guerrero, O.A. Estimating networks of Sustainable Development Goals. Inf. Manag. 2020, in press. [CrossRef]

11. Schneider, F.; Kläy, A.; Zimmermann, A.B.; Buser, T.; Ingalls, M.; Messerli, P. How can science support the 2030 Agenda for Sustainable Development? Four tasks to tackle the normative dimension of sustainability. Sustain. Sci. 2019, 14, 1593-1604. [CrossRef] 
12. Morton, S.; Pencheon, D.; Bickler, G. The Sustainable Development Goals provide an important framework for addressing dangerous climate change and achieving wider public health benefits. Public Health 2019, 174, 65-68. [CrossRef] [PubMed]

13. Annan-Diab, F.; Molinari, C. Interdisciplinarity: Practical approach to advancing education for sustainability and for the Sustainable Development Goals. Int. J. Manag. Educ. 2017, 15, 73-83. [CrossRef]

14. Alawneh, R.; Ghazali, F.; Ali, H.; Sadullah, A.F. A novel framework for integrating United Nations Sustainable Development Goals into sustainable non-residential building assessment and management in Jordan. Sustain. Cities Soc. 2019, $49,101612$. [CrossRef]

15. Sebestyén, V.; Bulla, M.; Rédey, Á.; Abonyi, J. Network model-based analysis of the goals, targets and indicators of sustainable development for strategic environmental assessment. J. Environ. Manag. 2019, 238, 126-135. [CrossRef] [PubMed]

16. Moldavska, A.; Welo, T. A Holistic approach to corporate sustainability assessment: Incorporating Sustainable Development Goals into sustainable manufacturing performance evaluation. J. Manuf. Syst. 2019, 50, 53-68. [CrossRef]

17. Veldhuizen, L.J.; Giller, K.E.; Oosterveer, P.; Brouwer, I.D.; Janssen, S.; van Zanten, H.H.; Slingerland, M.M.A. The Missing Middle: Connected action on agriculture and nutrition across global, national and local levels to achieve Sustainable Development Goal 2. Glob. Food Sec. 2020, 24, 100336. [CrossRef]

18. Avelar, A.B.A.; Silva-Oliveira, K.D.D.; Pereira, R.D.S. Education for advancing the implementation of the Sustainable Development Goals: A systematic approach. Int. J. Manag. Educ. 2019, 17, 100322. [CrossRef]

19. Horne, J.; Recker, M.; Michelfelder, I.; Jay, J.; Kratzer, J. Exploring entrepreneurship related to the Sustainable Development Goals-mapping new venture activities with semi-automated content analysis. J. Clean. Prod. 2020, 242, 118052. [CrossRef]

20. Miola, A.; Schiltz, F. Measuring Sustainable Development Goals performance: How to monitor policy action in the 2030 Agenda implementation. Ecol. Econ. 2019, 164, 106373. [CrossRef]

21. Moyer, J.D.; Bohl, D.K. Alternative pathways to human development: Assessing trade-offs and synergies in achieving the Sustainable Development Goals. Futures 2019, 105, 199-210. [CrossRef]

22. Allen, C.; Metternicht, G.; Wiedmann, T. Initial progress in implementing the Sustainable Development Goals (SDGs): A review of evidence from countries. Sustain. Sci. 2018, 13, 1453-1467. [CrossRef]

23. Caiado, R.G.G.; Leal Filho, W.; Quelhas, O.L.G.; Nascimento, D.L.M.; Ávila, L.V. A literature-based review on potentials and constraints in the implementation of the Sustainable Development Goals. J. Clean. Prod. 2018, 198, 1276-1288. [CrossRef]

24. Pizzi, S.; Caputo, A.; Corvino, A.; Venturelli, A. Management research and the UN Sustainable Development Goals (SDGs): A bibliometric investigation and systematic review. J. Clean. Prod. 2020, 276, 124033. [CrossRef]

25. Cordova, M.F.; Celone, A. SDGs and innovation in the business context literature review. Sustainability 2019, 11, 7043. [CrossRef]

26. García-Feijoo, M.; Eizaguirre, A.; Rica-Aspiunza, A. Systematic review of Sustainable-Development-Goal deployment in business schools. Sustainability 2020, 12, 440. [CrossRef]

27. Panfilo, S.; Blundo, B. Sustainable development goals and the strategic role of business: A systematic literature review. Bus. Strategy Environ. 2020, 29, 3220-3245.

28. Pham, M.T.; Rajić, A.; Greig, J.D.; Sargeant, J.M.; Papadopoulos, A.; McEwen, S.A. A scoping review of scoping reviews: Advancing the approach and enhancing the consistency. Res. Synth. Methods 2014, 5, 371-385. [CrossRef]

29. Arksey, H.; O’Malley, L. Scoping Studies: Towards a methodological framework. Int. J. Soc. Res. Methodol. 2005, 8, 19-32. [CrossRef]

30. Sucharew, H.; Macaluso, M. Methods for research evidence synthesis: The scoping review approach. J. Hosp. Med. 2019, 14, 416-418. [CrossRef]

31. Munn, Z.; Peters, M.D.J.; Stern, C.; Tufanaru, C.; McArthur, A.; Aromataris, E. Systematic review or scoping review? Guidance for authors when choosing between a systematic or scoping review approach. BMC Med. Res. Methodol. 2018, 18, 143. [CrossRef] [PubMed]

32. Gruber, T.R. Toward principles for the design of ontologies used for knowledge sharing. Int. J. Hum. Comput. Stud. 1995, 43, 907-928. [CrossRef]

33. Gungor, A.; Gupta, S.M. Issues in environmentally conscious manufacturing and product recovery: A survey. Comput. Ind. Eng. 1999, 36, 811-853. [CrossRef]

34. Ilgin, M.A.; Gupta, S.M. Environmentally conscious manufacturing and product recovery (ECMPRO): A review of the state of the art. J. Environ. Manag. 2010, 91, 563-591. [CrossRef] [PubMed]

35. Biermann, F.; Kanie, N.; Kim, R.E. Global governance by goal-setting: The novel approach of the UN Sustainable Development Goals. Curr. Opin. Environ. Sustain. 2017, 26-27, 26-31. [CrossRef]

36. Buchholz, W. Ontology. In Encyclopedia of Knowledge Management; Schwartz, D., Ed.; Idea Group Publishing: Hershey, PA, USA, 2006; pp. 694-702.

37. Park, J.; Ramaprasad, A. Toward ontology of designer-user interaction in the design process: A knowledge management foundation. J. Knowl. Manag. 2018, 22, 201-218. [CrossRef]

38. United Nations. Transforming Our World: The 2030 Agenda for Sustainable Development. 2015. Available online: https: / /sdgs.un.org/2030agenda (accessed on 6 August 2021).

39. United Nations Statistical Commission. SDG Indicators. 2017. Available online: https://unstats.un.org/sdgs/indicators/ indicators-list/ (accessed on 6 August 2021). 
40. Muff, K.; Kapalk, A.; Dyllick, T. The Gap Frame-Translating the SDGs into relevant national grand challenges for strategic business opportunities. Int. J. Manag. Educ. 2017, 15, 363-383. [CrossRef]

41. van Soest, H.L.; van Vuuren, D.P.; Hilaire, J.; Minx, J.C.; Harmsen, M.J.H.M.; Krey, V.; Popp, A.; Riahi, K.; Luderer, G. Analysing interactions among Sustainable Development Goals with Integrated Assessment Models. Glob. Transit. 2019, 1, $210-225$. [CrossRef]

42. Cai, Y.-J.; Choi, T.-M. A United Nations' Sustainable Development Goals perspective for sustainable textile and apparel supply chain management. Transport. Res. E-Log. 2020, 141, 102010. [CrossRef]

43. Paoli, A.D.; Addeo, F. Assessing SDGs: A methodology to measure sustainability. Athens J. Soc. Sci. 2019, 6, 229-250.

44. UNEA. A Contribution to the Global Follow-Up and Review in the 2016 High Level Political Forum (HLPF) on the Work of the United Nations Environment Programme. 2016. Available online: https://sustainabledevelopment.un.org/index.php?page= view \&type $=30022 \& n r=243 \&$ menu $=3170$ (accessed on 6 August 2021).

45. Boff, K.R. Revolutions and shifting paradigms in human factors \& ergonomics. Appl. Ergon. 2006, 37, 391-399.

46. Chung, A.Z.; Williamson, A. Theory versus practice in the human factors and ergonomics discipline: Trends in journal publications from 1960 to 2010. Appl. Ergon. 2018, 66, 41-51. [CrossRef]

47. Salvendy, G. Handbook of Human Factors and Ergonomics; John Wiley \& Sons, Inc.: New York, NY, USA, 1997.

48. van der Bijl-Brouwer, M.; Dorst, K. Advancing the strategic impact of human-centred design. Des. Stud. 2017, 53, 1-23. [CrossRef]

49. ISO 9241-210: 2019. Ergonomics of Human-System Interaction-Part 210: Human-Centred Design for Interactive Systems. Available online: https://www.iso.org/standard/77520.html (accessed on 6 August 2021).

50. Akao, Y. Quality Function Deployment: Integrating Customer Requirements into Product Design; Productivity Press: Cambridge, MA, USA, 1990.

51. Yamamoto, K. Kansei Engineering: The Art of Automotive Development at Mazda; Michigan Publishing: Ann Arbor, MI, USA, 1986.

52. Nagamachi, M. Kansei engineering: A new ergonomic consumer-oriented technology for product development. Int. J. Ind. Ergon. 1995, 15, 3-11. [CrossRef]

53. Suh, N.P. Axiomatic Design: Advances and Applications; Oxford University Press: Oxford, UK, 2001.

54. Eppinger, S.D.; Browning, T.R. Design Structure Matrix Methods and Applications; MIT Press: Cambridge, MA, USA, 2012.

55. Gu, P.; Hashemian, M.; Nee, A.Y.C. Adaptable design. CIRP Ann. 2004, 53, 539-557. [CrossRef]

56. Black, A. Empathic design: User focused strategies for innovation. In Proceedings of the Conference on New Product Development; IBC: London, UK, 1998; pp. 1-8.

57. Postma, C.E.; Zwartkruis-Pelgrim, E.; Daemen, E.; Du, J. Challenges of doing empathic design: Experiences from industry. Int. J. Des. 2012, 6, 59-70.

58. Mace, R.L. Universal design: Barrier free environments for everyone. Des. West 1985, 33, 147-152.

59. Lid, I.M. Developing the theoretical content in Universal Design. Scand. J. Disabil. Res. 2013, 15, 203-215. [CrossRef]

60. Persson, H.; Åhman, H.; Yngling, A.A.; Gulliksen, J. Universal design, inclusive design, accessible design, design for all: Different concepts-one goal? On the concept of accessibility-historical, methodological and philosophical aspects. Univ. Access Inf. Soc. 2015, 14, 505-526. [CrossRef]

61. Newell, A.F.; Gregor, P.; Morgan, M.; Pullin, G.; Macaulay, C. User-sensitive inclusive design. Univ. Access Inf. Soc. 2011, 10, 235-243. [CrossRef]

62. Ladner, R.E. Design for user empowerment. Interactions 2015, 22, 24-29. [CrossRef]

63. Wobbrock, J.O.; Kane, S.K.; Gajos, K.Z.; Harada, S.; Froehlich, J. Ability-based design: Concept, principles, and examples. ACM Trans. Access. Comput. 2011, 3, 1-27. [CrossRef]

64. Helander, M.; Landauer, T.; Prabhu, P. Handbook of Human-Computer Interaction; Elsevier: New York, NY, USA, 1997.

65. Preece, J.; Rogers, Y.; Sharp, H. Interaction Design: Beyond Human-Computer Interaction; John Wiley \& Sons, Inc.: New York, NY, USA, 2002.

66. ISO 9241-11: 2018. Ergonomics of human-system interaction-Part 11: Usability: Definitions and concepts. Available online: https: / / www.iso.org/standard/63500.html (accessed on 6 August 2021).

67. Nielsen, J. Usability Engineering; AP Professional: New York, NY, USA, 1993.

68. Beyer, H.; Holtzblatt, K. Contextual Design: Defining Customer-Centered Systems; Morgan Kaufmann Publishers Inc.: San Francisco, CA, USA, 1997.

69. Leonard, D.; Rayport, J.F. Spark innovation through empathic design. Harv. Bus. Rev. 1997, 75, 102-113. [PubMed]

70. Muller, M.J.; Kuhn, S. Participatory design. Commun. ACM 1993, 36, 24-28. [CrossRef]

71. Norman, D. The Design of Everyday Things; The Perseus Books Group: New York, NY, USA, 2013.

72. Soegaard, M. The Basics of User Experience Design; The Interaction Design Foundation: Aarhus, Denmark, 2018.

73. $\mathrm{Xu}, \mathrm{W}$. User experience design: Beyond user interface design and usability. In Ergonomics-A Systems Approach; Nunes, I.L., Ed.; InTech: Rijeka, Croatia, 2012; pp. 171-192.

74. Chou, J.-R. What would be the next design evolution under the auspices of Industry 4.0? In Cross-Cultural Design. User Experience of Products, Services, and Intelligent Environments; Rau, P.L., Ed.; Lecture Notes in Computer Science HCII 2020; Springer: Cham, Switzerland, 2020; Volume 12192, pp. 28-45.

75. Bendell, A. Introduction to Taguchi methodology. In Taguchi Methods, Proceedings of the 1988 European Conference; Elsevier Applied Science: London, UK, 1988; pp. 1-14. 
76. Taguchi, G. System of Experimental Design: Engineering Methods to Optimize Quality and Minimize Cost; American Suppliers Institute: Dearborn, MI, USA, 1987.

77. McDermott, R.E.; Mikulak, R.J.; Beauregard, M.R. The basics of FMEA; Productivity Press: New York, NY, USA, 1996.

78. Winner, R.I.; Pennell, J.P.; Bertrand, H.E.; Slusarczuk, M.M.G. The Role of Concurrent Engineering in Weapons System Acquisition; Institute for Defense Analyses: Alexandria, VA, USA, 1988.

79. Ma, Y.; Chen, G.; Thimm, G. Paradigm shift: Unified and associative feature-based concurrent engineering and collaborative engineering. J. Intell. Manuf. 2008, 19, 625-641. [CrossRef]

80. Willaert, S.S.A.; de Graaf, R.; Minderhoud, S. Collaborative engineering: A case study of Concurrent Engineering in a wider context. J. Eng. Technol. Manag. 1998, 15, 87-109. [CrossRef]

81. Ma, J.; Kremer, G.E.O. A systematic literature review of modular product design (MPD) from the perspective of sustainability. Int. J. Adv. Manuf. Technol. 2016, 86, 1509-1539. [CrossRef]

82. Motavalli, S. Review of reverse engineering approaches. Comput. Ind. Eng. 1998, 35, 25-28. [CrossRef]

83. McMahon, C.; Browne, J. CAD/CAM: Principles, Practice, and Manufacturing Management; Addison-Wesley: Boston, MA, USA, 1998.

84. Pedagopu, V.M.; Kumar, M. Integration of CAD/CAPP/CAM/CNC to augment the efficiency of CIM. Int. Rev. Appl. Eng. Res. 2014, 4, 171-176.

85. Walker, R.A.; Shah, S.C.; Gupta, N.K. Computer-Aided Engineering (CAE) for System Analysis. Proc. IEEE 1984, $72,1732-1745$. [CrossRef]

86. Chiu, M.-C.; Kremer, G.E.O. An investigation of the applicability of DfX tools during design concept evolution. Int. J. Prod. Dev. 2011, 13, 132-167. [CrossRef]

87. Kuo, T.-C.; Huang, S.H.; Zhang, H.-C. Design for manufacture and design for ' $X$ ': Concepts, applications, and perspectives. Comput. Ind. Eng. 2001, 41, 241-260. [CrossRef]

88. Benabdellah, A.C.; Bouhaddou, I.; Benghabrit, A.; Benghabrit, O. A systematic review of design for X techniques from 1980 to 2018: Concepts, applications, and perspectives. Int. J. Adv. Manuf. Technol. 2019, 102, 3473-3502. [CrossRef]

89. Poli, C. Design for Manufacturing: A Structured Approach; Elsevier Science \& Technology Books: Amsterdam, The Netherlands, 2001.

90. Boothroyd, G. Design for assembly-The key to design for manufacture. Int. J. Adv. Manuf. Technol. 1987, 2, 3-11. [CrossRef]

91. Erixon, G. Design for modularity. In Design for X; Huang, G.Q., Ed.; Springer: Dordrecht, The Netherlands, 1996 ; pp. $356-379$.

92. Smets, L.P.M.; van Houtum, G.J.J.A.N.; Langerak, F. Design for availability: A holistic approach to create value for manufacturers and customers of capital goods. J. Syst. Sci. Syst. Eng. 2012, 21, 403-421. [CrossRef]

93. Mörtl, M.; Schmied, C. Design for cost-A review of methods, tools and research directions. J. Indian Inst. Sci. 2015, 95, 379-404.

94. Mettas, A. Design for reliability: Overview of the process and applicable Techniques. Int. J. Perform. Eng. 2010, 6, 577-586.

95. Kasarda, M.E.; Terpenny, J.P.; Inman, D.; Precoda, K.R.; Jelesko, J.; Sahin, A.; Park, J. Design for adaptability (DFAD)—A new concept for achieving sustainable design. Robot. Comput. Integr. Manuf. 2007, 23, 727-734. [CrossRef]

96. Morup, M. A new design for quality paradigm. J. Eng. Des. 1992, 3, 63-80. [CrossRef]

97. Martin, M.; Hausman, W.; Ishii, K. Design for variety. In Product Variety Management; Ho, T.H., Tang, C.S., Eds.; International Series in Operations Research \& Management Science; Springer: Boston, MA, USA, 1998; Volume 10, pp. $103-122$.

98. Reinman, G.; Ayer, T.; Davan, T.; Devore, M.; Finley, S.; Glanovsky, J.; Gray, L.; Hall, B.; Jones, C.; Learned, A.; et al. Design for variation. Qual. Eng. 2012, 24, 317-345. [CrossRef]

99. Bralla, J.G. Design for Excellence; McGraw-Hill: New York, NY, USA, 1996.

100. Allshuller, G. And Suddenly the Inventor Appeared: TRIZ, the Theory of Inventive Problem Solving; Technical Innovation Center, Inc.: Worcester, MA, USA, 1996.

101. Chechurin, L.; Borgianni, Y. Understanding TRIZ through the review of top cited publications. Comput. Ind. 2016, 82, 119-134. [CrossRef]

102. Ekmekci, I.; Koksal, M. Triz methodology and an application example for product development. Procedia Soc. Behav. Sci. 2015, 195, 2689-2698. [CrossRef]

103. Souchkov, V. TRIZ for business and management: State of the art. In Proceedings of the TRIZ Developers Summit 2019, Minsk, Belarus, 13-15 June 2019.

104. Chai, K.-H.; Zhang, J.; Tan, K.-C. A TRIZ-based method for new service design. J. Serv. Res. 2005, 8, 48-66. [CrossRef]

105. Vaneker, T.; van Diepen, T. Design support for maintenance tasks using TRIZ. Procedia CIRP 2016, 39, 67-72. [CrossRef]

106. Berdonosov, V. Concept of the TRIZ evolutionary approach in education. Procedia Eng. 2015, 131, 721-730. [CrossRef]

107. Renev, I.A.; Chechurin, L.S. Application of TRIZ in building industry: Study of current situation. Procedia CIRP 2016, 39, 209-215. [CrossRef]

108. Li, Y.-X.; Wu, Z.-X.; Dincer, H.; Kalkavan, H.; Yuksel, S. Analyzing TRIZ-based strategic priorities of customer expectations for renewable energy investments with interval type-2 fuzzy modeling. Energy Rep. 2021, 7, 95-108. [CrossRef]

109. Moussa, F.Z.B.; Rasovska, I.; Dubois, S.; DE GUIO, R.; Benmoussa, R. Reviewing the use of the theory of inventive problem solving (TRIZ) in green supply chain problems. J. Clean. Prod. 2017, 142, 2677-2692. [CrossRef]

110. Russoa, D.; Regazzonib, D.; Montecchi, T. Eco-design with TRIZ laws of evolution. Procedia Eng. 2011, 9, 311-322. [CrossRef]

111. Feniser, C.; Burz, G.; Mocan, M.; Ivascu, L.; Gherhes, V.; Otel, C.C. The evaluation and application of the TRIZ method for increasing Eco-Innovative levels in SMEs. Sustainability 2017, 9, 1125. [CrossRef]

112. Russo, D.; Spreafico, C. TRIZ-based guidelines for eco-improvement. Sustainability 2020, 12, 3412. [CrossRef] 
113. Fresner, J.; Jantschgi, J.; Birkel, S.; Bärnthaler, J.; Krenn, C. The theory of inventive problem solving (TRIZ) as option generation tool within cleaner production projects. J. Clean. Prod. 2010, 18, 128-136. [CrossRef]

114. D'Anna, W.; Cascini, G. Supporting sustainable innovation through TRIZ system thinking. Procedia Eng. 2011, 9, 145-156. [CrossRef]

115. Al-Betar, M.A.; Alomari, O.A.; Abu-Romman, S.M. A TRIZ-inspired bat algorithm for gene selection in cancer classification. Genomics 2020, 112, 114-126. [CrossRef]

116. Papanek, V. Design for the Real World: Human Ecology and Social Change; Pantheon Books: New York, NY, USA, 1972.

117. Whiteley, N. Design for Society; Reaktion Books: London, UK, 1993.

118. Sachs, A.; Banz, C.; Krohn, M. Social Design: Participation and Empowerment; Lars Müller Publishers: Zurich, Switzerland, 2018.

119. Thorpe, A.; Gamman, L. Design with society: Why socially responsive design is good enough. CoDesign 2011, 7, 217-230. [CrossRef]

120. de Vere, I.; Melles, G. Integrating 'designerly' ways with engineering science: A catalyst for change within product design and development. In Handbook of Research on Trends in Product Design and Development: Technological and Organizational; Silva, A., Simões, R., Eds.; IGI Global: Hershey, PA, USA, 2011; pp. 173-194.

121. Atak, A.; Şık, A. Designer's ethical responsibility and ethical design. Univ. J. Mech. Eng. 2019, 7, 255-263. [CrossRef]

122. Wasson, C. Design anthropology. Gen. Anthropol. 2016, 23, 1-11. [CrossRef]

123. Fuad-Luke, A. Design Activism: Beautiful Strangeness for a Sustainable World; Routledge: London, UK, 2009.

124. Petermans, A.; Cain, R. Design for Wellbeing: An Applied Approach; Routledge: London, UK, 2019.

125. Bertoni, M.; Larsson, A.; Ericson, Å.; Chirumalla, K.; Larsson, T.; Isaksson, O.; Randall, D. The rise of social product development. Int. J. Netw. Virtual Organ. 2012, 11, 188-207. [CrossRef]

126. Forbes, H.; Schaefer, D. Social product development: The democratization of design, manufacture and innovation. Procedia CIRP 2017, 60, 404-409. [CrossRef]

127. Ornelas, Y.; Gregory, J. Design for social inclusion. In Proceedings of the Design Rigor \& Relevance, IASDR 2009, Seoul, Korea, 18-22 October 2009.

128. Souleles, N. Design for social change and design education: Social challenges versus teacher-centred pedagogies. Des. J. 2017, 20, S927-S936. [CrossRef]

129. Design for Social Impact: How-to Guide. The Rockefeller Foundation. Available online: https://new-ideo-com.s3.amazonaws. com/assets / files/pdfs/news/IDEO_RF_Guide.pdf (accessed on 6 August 2021).

130. Pack, A.T.; Phipps, E.R.; Mattson, C.A.; Dahlin, E.C. Social impact in product design: An exploration of current industry practices. J. Mech. Des. 2020, 142, 071702. [CrossRef]

131. Vanclay, F. International principles for social impact assessment. Impact Assess. Proj. Apprais. 2003, 21, 5-12. [CrossRef]

132. Moltesen, A.; Bonou, A.; Wangel, A.; Bozhilova-Kisheva, K.P. Social life cycle assessment: An introduction. In Life Cycle Assessment; Hauschild, M., Rosenbaum, R., Olsen, S., Eds.; Springer: Cham, Switzerland, 2018; pp. 401-422.

133. Chick, A. Design for social innovation: Emerging principles and approaches. Iridescent 2012, 2, 78-90. [CrossRef]

134. Manzini, E. Design for Social Innovation vs. Social Design. DESIS Network: Design for Social Innovation towards Sustainability. 2014. Available online: https:/ / www.desisnetwork.org/2014/07/25/design-for-social-innovation-vs-social-design/ (accessed on 6 August 2021).

135. Carroll, A.B.; Shabana, K.M. The business case for corporate social responsibility: A review of concepts, research and practice. Int. J. Manag. Rev. 2010, 12, 85-105. [CrossRef]

136. Maon, F.; Lindgreen, A.; Swaen, V. Designing and implementing corporate social responsibility: An integrative framework grounded in theory and practice. J. Bus. Ethics 2009, 87, 71-89. [CrossRef]

137. ISO 26000: 2010. Guidance on Social Responsibility. Available online: https://www.iso.org/standard/42546.html (accessed on 6 August 2021).

138. Zotter, K.A. "End-of-pipe" versus "process-integrated" water conservation solutions-A comparison of planning, implementation and operating phases. J. Clean. Prod. 2004, 12, 685-695. [CrossRef]

139. Gupta, M.C. Environmental management and its impact on the operations function. Int. J. Oper. Prod. Manag. 1995, 15, 34-51. [CrossRef]

140. Vezzoli, C.; Ceschin, F.; Osanjo, L.; M’Rithaa, M.K.; Moalosi, R.; Nakazibwe, V.; Diehl, J.C. Design for sustainability: An introduction. In Designing Sustainable Energy for All, Green Energy and Technology; Springer: Cham, Switzerland, 2018 ; pp. 103-124.

141. Hart, S.L. A natural-resource-based view of the firm. Acad. Manag. Rev. 1995, 20, 986-1014. [CrossRef]

142. Stitzhal, D. Product stewardship: Can it drive green design? Environ. Qual. Manag. 2011, 20, 25-41. [CrossRef]

143. Lyle, J.T. Regenerative Design for Sustainable Development; John Wiley \& Sons: New York, NY, USA, 1994.

144. Dowie, T. Green design. World Class. Des. Manuf. 1994, 1, 32-38. [CrossRef]

145. Brezet, H.; van Hemel, C. Ecodesign: A Promising Approach to Sustainable Production and Consumption; United Nations Environment Programme, Industry and Environment, Cleaner Production; UNEP\&TU Delft: Paris, France, 1997.

146. Braungart, M.; McDonough, W.; Bollinger, A. Cradle-to-cradle design: Creating healthy emissions-A strategy for eco-effective product and system design. J. Clean. Prod. 2007, 15, 1337-1348. [CrossRef]

147. McLennan, J.F. The Philosophy of Sustainable Design; Ecotone Publishing Company LLC: Kansas City, MO, USA, 2004.

148. Chapman, J. Emotionally Durable Design: Objects, Experiences and Empathy; Earthscan Publications Ltd.: New York, NY, USA, 2005. 
149. Lilley, D. Design for sustainable behaviour: Strategies and perceptions. Des. Stud. 2009, 30, 704-720. [CrossRef]

150. Chiu, M.-C.; Chu, C.-H. Review of sustainable product design from life cycle perspectives. Int. J. Preci. Eng. Manuf. 2012, 13, 1259-1272. [CrossRef]

151. Cohen, Y.H.; Reich, Y. Biomimetic Design Method for Innovation and Sustainability; Springer International Publishing: Cham, Switzerland, 2016.

152. Kalisvaart, S.H.; van der Horst, T.J.J. Implementing ecological product design. World Class Des. Manuf. 1995, 2, 21-30. [CrossRef]

153. Ehrenfeld, J.R. Industrial ecology: A framework for product and process design. J. Clean. Prod. 1997, 5, 87-95. [CrossRef]

154. Forlizzi, J. The product ecology: Understanding social product use and supporting design culture. Int. J. Des. 2008, 2, 11-20.

155. Argument, L.; Lettice, F.; Bhamra, T. Environmentally conscious design: Matching industry requirements with academic research. Des. Stud. 1998, 19, 63-80. [CrossRef]

156. Wang, M.H. A systematic framework for environmentally conscious design. In Handbook of Environmentally Conscious Manufacturing; Madu, C.N., Ed.; Springer: Boston, MA, USA, 2001.

157. Alting, L. Life-cycle design of products: A new opportunity for manufacturing enterprises. In Concurrent Engineering: Automation, Tools E Techniques; Kusiak, A., Ed.; Wiley: New York, NY, USA, 1993; pp. 1-17.

158. Mule, J.Y. Design for disassembly approaches on product development. Int. J. Sci. Eng. Res. 2012, 3, 1-5.

159. Cohen, B. Design for reuse. In VHDL Answers to Frequently Asked Questions; Springer: Boston, MA, USA, 1998 ; pp. $313-339$.

160. Kriwet, A.; Zussman, E.; Seliger, G. Systematic integration of design-for-recycling into product design. Int. J. Prod. Econ. 1995, 38, 15-32. [CrossRef]

161. Desai, A.; Mital, A. Design for maintenance: Basic concepts and review of literature. Int. J. Prod. Dev. 2006, 3, 77-121. [CrossRef]

162. Tortorella, M. Design for maintainability. In Reliability, Maintainability, and Supportability: Best Practices for Systems Engineers; John Wiley \& Sons, Inc.: Hoboken, NJ, USA, 2015; pp. 356-375.

163. Goffin, K. Design for supportability: Essential component of new product development. Res. Technol. Manag. 2000, 43, 40-47. [CrossRef]

164. Navtn-Chandra, D. The recovery problem in product design. J. Eng. Des. 1994, 5, 65-86. [CrossRef]

165. Dewhurst, P.; Abbatiello, N. Design for service. In Design for X; Huang, G.Q., Ed.; Springer: Dordrecht, The Netherlands, 1996; pp. 298-317.

166. Gobbo Junior, O.; Borsato, M. A method to support design for serviceability in the early stages of new product development. Int. J. Comput. Integr. Manuf. 2021, 34, 41-56. [CrossRef]

167. Newcomb, P.J.; Bras, B.; Rosen, D.W. Implications of modularity on product design for the life cycle. J. Mech. Des. 1998, 120, 483-490. [CrossRef]

168. Fiksel, J. Design for Environment: Creating Eco-Efficient Products and Processes; McGraw-Hill: New York, NY, USA, 1996.

169. Clark, G.; Kosoris, J.; Hong, L.N.; Crul, M. Design for sustainability: Current trends in sustainable product design and development. Sustainability 2009, 1, 409-424. [CrossRef]

170. Ceschin, F.; Gaziulusoy, I. Evolution of design for sustainability: From product design to design for system innovations and transitions. Des. Stud. 2016, 47, 118-163. [CrossRef]

171. Manzini, E.; Vezzoli, C. Product-Service Systems and Sustainability: Opportunities for Sustainable Solutions; UNEP (United Nations Environment Programme): Paris, France, 2003.

172. Vasantha, G.V.A.; Roy, R.; Lelah, A.; Brissaud, D. A review of product-service systems design methodologies. J. Eng. Des. 2012, 23, 635-659. [CrossRef]

173. Fargnoli, M.; Lleshaj, A.; Lombardi, M.; Sciarretta, N.; Di Gravio, G. A BIM-based PSS approach for the management of maintenance operations of building equipment. Buildings 2019, 9, 139. [CrossRef]

174. Labbate, R.; Silva, R.F.; Rampasso, I.S.; Anholon, R.; Quelhas, O.L.G.; Leal Filho, W. Business models towards SDGs: The barriers for operationalizing Product-Service System (PSS) in Brazil. Int. J. Sustain. Dev. World Ecol. 2021, 28, 350-359. [CrossRef]

175. Moreno, M.; De los Rios, C.; Rowe, Z.; Charnley, F. A conceptual framework for circular design. Sustainability $2016,8,937$. [CrossRef]

176. Mestre, A.; Cooper, T. Circular product design. A multiple loops life cycle design approach for the circular economy. Des. J. 2017, 20, 1620-1635. [CrossRef]

177. Gundes, S. The use of life cycle techniques in the assessment of sustainability. Procedia Soc. Behav. Sci. 2016, $216,916-922$. [CrossRef]

178. Sonnemann, G.; Gemechu, E.D.; Remmen, A.; Frydendal, J.; Jensen, A.A. Life cycle management: Implementing sustainability in business practice. In Life Cycle Management, LCA Compendium-The Complete World of Life Cycle Assessment; Sonnemann, G., Margni, M., Eds.; Springer: Dordrecht, The Netherlands, 2015; pp. 7-21.

179. Keoleian, G.A. The application of life cycle assessment to design. J. Clean. Prod. 1993, 1, 143-149. [CrossRef]

180. Ayres, R.U. Life cycle analysis: A critique. Resour. Conserv. Recycl. 1995, 14, 199-223. [CrossRef]

181. Hunkeler, D.; Rebitzer, G.; Lichtenvort, K. Environmental Life Cycle Costing; CRC Press: Boca Raton, FL, USA, 2008.

182. van der Giesen, C.; Kleijn, R.; Kramer, G.; Guinée, J. Towards application of life cycle sustainability analysis. Rev. Métall. 2013, 110, 29-36. [CrossRef]

183. Suh, S.; Huppes, G. Methods in the life cycle inventory of a product. J. Clean. Prod. 2005, 13, 687-697. [CrossRef] 
184. Hauschild, M.Z.; Huijbregts, M.A.J. Introducing life cycle impact assessment. In Life Cycle Impact Assessment, LCA Compendium-The Complete World of Life Cycle Assessment; Hauschild, M., Huijbregts, M., Eds.; Springer: Dordrecht, The Netherlands, 2015; pp. 1-16.

185. Jeswiet, J. Life cycle engineering. In The International Academy for Production Engineering, CIRP Encyclopedia of Production Engineering; Laperrière, L., Reinhart, G., Eds.; Springer: Berlin/Heidelberg, Germany, 2014.

186. Fargnoli, M.; Kimura, F. Screening life cycle modelling for sustainable product design. In Innovation in Life Cycle Engineering and Sustainable Development; Brissaud, D., Tichkiewitch, S., Zwolinski, P., Eds.; Springer: Dordrecht, The Netherlands, 2006; pp. 281-292.

187. BS 8887-3:2018. Design for Manufacture, Assembly, Disassembly and End-of-Life Processing (MADE). Guide to Choosing an Appropriate End-of-Life Design Strategy. Available online: https: / shop.bsigroup.com/ProductDetail?pid=000000000030366502 (accessed on 6 August 2021).

188. UNE 150008:2008. Environmental Risk Analysis and Assessment. Available online: https://www.en-standard.eu/une-150008-2 008-environmental-risk-analysis-and-assessment./ (accessed on 6 August 2021).

189. IEC 62430:2019. Environmentally Conscious Design (ECD)-Principles, Requirements and Guidance. Available online: https: //www.iso.org/standard/79064.html (accessed on 6 August 2021).

190. ISO 14006:2020. Environmental Management Systems-Guidelines for Incorporating Ecodesign. Available online: https:/ /www. iso.org/standard/72644.html (accessed on 6 August 2021).

191. Finkbeiner, M.; Inaba, A.; Tan, R.B.H.; Christiansen, K.; Klüppel, H.-J. The new international standards for life cycle assessment: ISO 14040 and ISO 14044. Int. J. Life Cycle Assess. 2006, 11, 80-85. [CrossRef]

192. ISO 14091:2021. Adaptation to Climate Change-Guidelines on Vulnerability, Impacts and Risk Assessment. Available online: https://www.iso.org/standard/68508.html (accessed on 6 August 2021).

193. Hochschorner, E.; Finnveden, G. Evaluation of two simplified life cycle assessment methods. Int. J. Life Cycle Assess. 2003, 8, 119-128. [CrossRef]

194. Brezet, H. (Ed.) PROMISE manual. In Delft University of Technology; TME Institute and TNO product Centre: Delft, The Netherlands, 1996.

195. Fussler, C.; James, P. Driving Eco-Innovation: A Breakthrough Discipline for Innovation and Sustainability; Pitman Publishing: London, UK, 1996.

196. Wimmer, W. The ECODESIGN checklist method: A redesign tool for environmental product improvements. In Proceedings of the First International Symposium on Environmentally Conscious Design and Inverse Manufacturing, Tokyo, Japan, 1-3 February 1999; pp. 685-688.

197. Jones, E.; Stanton, N.A.; Harrison, D. Applying structured methods to Eco-innovation: An evaluation of the Product Ideas Tree diagram. Des. Stud. 2001, 22, 519-542. [CrossRef]

198. Cramer, J. The development and implementation of STRETCH: Selection of strategic environmental challenges. Stud. Environ. Sci. 1998, 72, 893-908.

199. Persson, J.-G. Eco-indicators in product development. J. Eng. Manuf. 2001, 215, 627-635. [CrossRef]

200. Wimmer, W.; Züst, R. Ecodesign Pilot: Product Investigation, Learning and Optimization Tool for Sustainable Product Development; Springer: Dordrecht, The Netherlands, 2003.

201. Bruccoleri, M.; Mazzola, E.; Sferlazzo, G. Explaining the relationship between socially responsible products and the operations of the firm: The case of equine assisted therapy. J. Clean. Prod. 2018, 195, 839-850. [CrossRef]

202. Rocha, C.S.; Antunes, P.; Partidário, P. Design for sustainability models: A multiperspective review. J. Clean. Prod. 2019, 234, 1428-1445. [CrossRef]

203. Bermejo-Martín, G.; Rodríguez-Monroy, C. Design thinking methodology to achieve household engagement in urban water sustainability in the city of Huelva (Andalusia). Water 2020, 12, 1943. [CrossRef]

204. Buhl, A.; Schmidt-Keilich, M.; Muster, V.; Blazejewski, S.; Schrader, U.; Harrach, C.; Schäfer, M.; Süßbauer, E. Design thinking for sustainability: Why and how design thinking can foster sustainability-oriented innovation development. J. Clean. Prod. 2019, 231, 1248-1257. [CrossRef]

205. Maher, R.; Maher, M.; Mann, S.; McAlpine, C.A. Integrating design thinking with sustainability science: A research through design approach. Sustain. Sci. 2018, 13, 1565-1587. [CrossRef] [PubMed] 